UNITED STATES DEPARTIENT OF THE INTERIOR

GEOLOGICAL SURVEY

ANALOG-MODEL STUDIES OF GROUND-WATER HYDROLOGY

IN THE HOUSTON DISTRICT, TEXAS

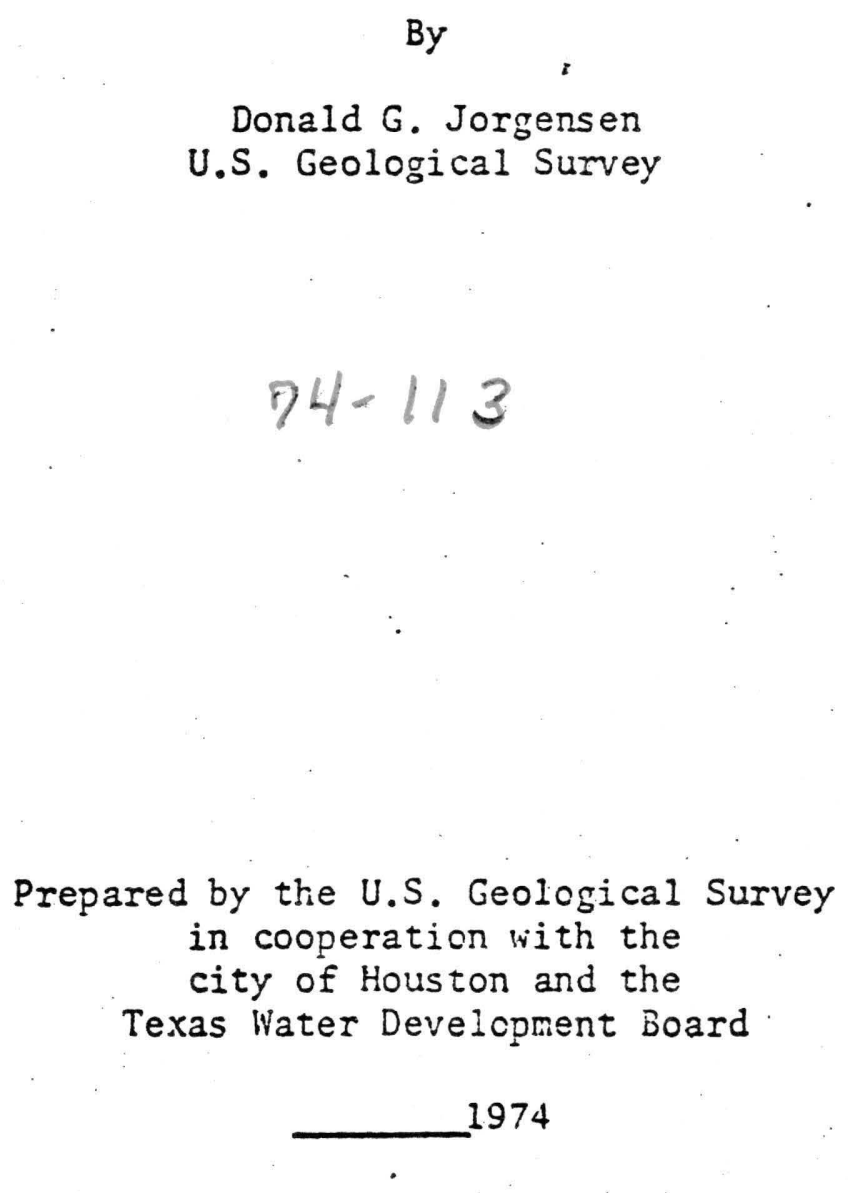

Donald G. Jorgensen

U.S. Geological Survey

$94-113$

in cooperation with the

city of Houston and the

Texas Water Develcpment Board 


\section{CONTENTS}

\section{Page}

Abstracț-

Introduction-1. 3

Purpose and scope of the project- 3

Description of the area- 5

Previous studies- 6

Acknow ledgments-1 7

Geohydrology- 8

Description of the water-bearing units- 10

Chicot aquifer. 10

Evangeline aquifer-12

Burkeville confining layer-13

Declines in the altitudes of the potentiometric surfaces--.- 13

Houston area- 14

Pasadena area-15 15

Katy area-1 16

Baytown-La Porte area-_._. 16

NASA area-1- 17

Texas City area- 18

Alta Loma area-1 18

Salt-water encroachment-1 19

Land-surface subsidence-1 20 
Analog-model studies-1-2 25

Theory of the electric analog model- 25

Description of the model- 26

Hydrologic properties and parameters modeled-..... 28

Ground-water withdrawals 28

Aquifer transmissivity- 29

Aquifer storage coefficient- 31

Storage coefficient of clays-1 31

Quantity of water from clay storage-1 32

Vertical hydraulic conductivity and vertical leakage---- 33

Declines in the altitudes of the potentiometric surfaces- 34

Calibration of the model and results 35

Model sensitivity-1 38

Simulations of the altitudes of the potentiometric

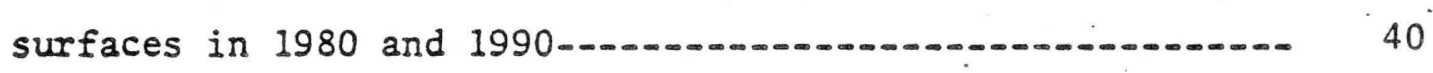

Alternative A- 40

Alternative B-1 44

Alternative C-1 45

Alternative D-. 46 
Analog-model studies--Concluded

Limitations on use of the analog model- 48

Data required for improvement of the model- 48

Summary-1 50

References cited-1 54 


\section{ILLUSTRATIONS}

Page

Figure 1. Map showing location and extent of the Houston

district-1-2 -

2. Map showing locations of pumped areas and

selected wells in the Houston district

3. Chart showing correlation of hydrologic units from northem Montgomery County to the Gulf of Mexico-

4. Map showing approximate altitude of the base of the Chicot aquifer-

5. Map showing approximate altitude of the base of

the upper unit of the Chicot aquifer

6. Map showing estimated transmissivity and storage coefficient of the lower unit of the Chicot aquifer and the Chicot aquifer undifferentiated....--

7. Map showing approximate altitude of the base of

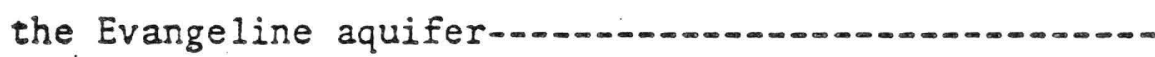

8. Map showing estimated transmissivity and storage coefficient of the Evangeline aquifer-.....

9. Graph showing withdrawals of ground water from 1890 to 1970 and predicted withdrawals from 1971 to $1980--$ 65

10. Map showing approximate and simulated decline in the altitude of the potentiometric surface in the lower unit of the Chicot aquifer and the Chicot aquifer undifferentiated, 1890-1953 


\section{ILLUSTRATIO:NS--Continued}

Page

Figure 11. Map showing approximate and simulated decline in the altitude of the potentiometric surface in the lower unit of the Chicot aquifer and the Chicot aquifer undifferentiated, 1890-1960-.....--

12. Map showing approximate and simulated decline in the altitude of the potentiometric surface in the lower unit of the Chicot aquifer and the Chicot aquifer undifferentiated, 1890-1970-......

13. Map showing approximate and simulated decline in the altitude of the potentiometric surface in -the Evangeline aquifer, $1890-1953$

14. Map showing approximate and simulated decline in the altitude of the potentiometric surface in the Evangeline aquifer, 1890-1960

15. Map showing approximate and simulated decline in the altitude of the potentiometric surface in the Evangeline aquifer, 1890-1970

16. Hydrographs showing depth to water in wells in the Houston area-.-

17. Hydrographs showing depth to water in wells in the

- Pasadena area-C.

18. Hydrographs showing depth to water in wells in the

Katy area-1 


\section{ILLUSTRATIONS--Continued}

Page

Figure 1.9. Hydrographs showing depth to water in wells in the

Baytown-La Porte area-_. 75

20. Hydrograph showing depth to water in a well in

the NASA area-1. 76

21. Hydrographs showing depth to water in wells in the

Texas City and Alta Loma areas-1. 77

22. Graph showing percentage of clay compaction with

depth at wel1 LJ-65-22-103-

78

23. Graph showing relation of land-surface subsidence

to the decline in the altitude of the potenti-

-ometric surface and the percentage of clay in

an aquifer

24. Map showing approximate land-surface subsidence,

$1906-43-1080$

25. Map showing land-surface subsidence, 1943-64-_...-. 81

26. Photographs of the electric analog model of the

Houston district-1. 82

27. Diagram illustrating a simple electric analog

model-1-2-1 -

28. Diagrams illustrating the analogy of electrical

current to ground-water flow- 84

29. Graph showing volume of water derived from clay

compaction-1. 


\section{ILLUSTRATIONS--COntinued}

Page

Figure 30. Graph showing sensivity of the model to vertical hydraulic conductivity

31. Map showing simulated decline in the altitude of the potentiometric surface in the lower unit of the Chicot aquifer and the Chicot aquifer undifferentiated, 1890-1980, alternative A-_.....-

32. Map showing simulated decline. in the altitude of the potentiometric surface of the Evangeline aquifer, 1890-1980, alternative A-

33. Map showing simulated decline in the altitude of the potentiometric surface in the lower unit of the Chicot aquifer and thie Chicot aquifer undifferentiated, 1890-1990, resulting from pumping from 1890-1980, alternative A

34. Map showing simulated decline in the altitude of the potentiometric surface in the Evangeline aquifer, 1890-1990, resulting from pumping from 1890-1980, alternative

35. Map showing simulated decline in the altitude of the potentiometric surface in the lower unit of the Chicot aquifer and the Chicot aquifer

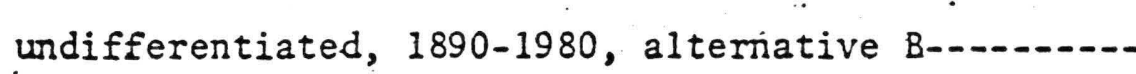




\section{ILLUSTRATIONS--Concluded}

Page

Figure 36. Map showing simulated decline. in the altitude of

the potentiometric surface in the Evangeline

aquifer, 1890-1980, alternative B

37. Map showing simulated decline. in the altitude of the potentiometric surface in the lower unit of the Chicot aquifer and the Chicot aquifer undifferentiated, 1890-1990, alternative C-.-.-.-

38. Map showing simulated decline in the altitude of the potentiometric surface in the Evangeline aquifer, 1890-1990, alternative C

39. Map showing simulated decline in the altitude of the potentiometric surface in the Evangeline aquifer, 1890-1990, altemative D

40. Map showing simulated decline in the altitude, of the potentiometric surface in the lower unit of the Chicot aquifer and the Chicot aquifer undifferentiated, 1890-1990, alternative D-1-.-.-. . 96 


\section{TABLES}

Page

Table 1. Geologic and hydrologic units used in this report and in recent reports on nearby areas

2. Approximate volume of water derived from clay

compaction in the Houston district-1..

3. Hydrologic budget used to verify the analog

model-1 - 


\title{
ANALOG-MODEL STUDIES OF GROUND-WATER HYDROLOGY \\ IN THE HOUSTON DISTRICT, TEXAS
}

By

Donald G. Jorgensen

U.S. Geological Survey

\begin{abstract}
The major water-bearing units in the Houston district are the Chicot and the Evangeline aquifers. The Chicot aquifer overlies the Evangeline aquifer, which is underlain by the Burkeville confining layer. Both aquifers consist of unconsolidated and discontinuous layers of sand and clay that dip toward the Gulf of Mexico.
\end{abstract}

Heavy pumping of fresh water has caused large declines in the altitudes of the potentiometric surfaces in both aquifers and has created large cones of depression around Houston. The declines have caused compaction of clay layers, which has resulted in land-surface subsidence and the movement of saline ground water toward the centers of the cones of depression.

An electric analog model was used to study the hydrologic system and to simulate the declines in the altitudes of the potentiometric surfaces for several alternative plans of ground-water development. The results indicate that the largest part of the pumped water comes from storage in the water-table part of the Chicot aquifer. Vertical leakage from the aquifers and water derived from the compaction of clay layers in the aquifers are also large sources of the water being pumped.

$$
=1-
$$


The response of the system, as observed on the model, indicates that development of additional ground-water supplies from the water-table part of the Chicot aquifer north of Houston would result in a minimum decline of the altitudes of the potentiometric surfaces. Total withdrawals of about 1,000 million gallons ( 3.8 million cubic meters) per day may be possible without seriously. increasing subsidence or salt-water encroachment.

Analyses of the recovery of water levels indicate that both landsurface subsidence and salt-water encroachment could be reduced by artificially recharging the artesian part of the aquifer. 


\section{INTRODUCTION}

\section{Purpose and Scone of the Project}

$\therefore$ Continual declines of water levels in wells, land-surface subsidence, and salt-water encroachment are problems related to ground-water pumping in the Houston district that necessitate additional studies of the hydrologic system.

This study was begun in 1970 by the U.S. Geological Survey in cooperation with the city of Houston and the Texas Hater Development Board. The principal purpose was to develop a means for forecasting declines in the altitudes of the potentiometric surfaces (levels to which water will rise in tightly cased wells) under various conditions of pumping. Because of the complexity of the hydrologic system, an electric analog model was chosen as the most suitable device for analyzing the system and simulating future responses.

This report presents the results of the geologic and hydrologic studies, discusses the theory and construction of the analog model, and presents the simulation of the declines in the altitudes of the potentiometric surfaces as determined by using the model.

Most of the data upon which this report is based are available in reports by the U.S. Geological Survey and the Texas Water Development Board (see references) or in the files of the U.S. Geological Survey in Houston. Data are obtained through a continuing cooperative program of the U.S. Geological Survey, the Texas Water Development Board, the city of Houston, and the city of Galveston. 
For those readers interested in using the metric system, metric equivalents of English units of measurements are given in parentheses. The English units used in this report may be converted to metric units by the following conversion factors:

\begin{tabular}{|c|c|c|c|c|c|}
\hline \multicolumn{2}{|l|}{ From } & \multirow{2}{*}{\multicolumn{2}{|c|}{ Nultiply by }} & \multicolumn{2}{|c|}{ To obtain } \\
\hline Unit & $\begin{array}{l}\text { Abbrevi- } \\
\text { ation }\end{array}$ & & & Unit & $\begin{array}{l}\text { Abbrevi- } \\
\text { ation }\end{array}$ \\
\hline cubic foot & $f t^{3}$ & 0.028317 & & cubic meter & $m^{3}$ \\
\hline foot & $f t$ & 0.3048 & & meter & $\mathrm{m}$ \\
\hline foot per day & ft/day & 0.3048 & & meter per day & $\mathrm{m} / \mathrm{day}$ \\
\hline $\begin{array}{l}\text { foot squared } \\
\text { per day }\end{array}$ & $f t^{2} /$ day & 0.0929 & & $\begin{array}{l}\text { meter squared } \\
\text { per day }\end{array}$ & $\mathrm{m}^{2} /$ day \\
\hline inch & in & 2.540 & & centimeter & $\mathrm{cm}$ \\
\hline million gallons & $10^{6} \mathrm{gal}$ & 3,785 & & cubic meters & $\mathrm{m}^{3}$ \\
\hline square mile & $m i^{2}$ & 2.590 & $t$ & square kilometer & $\mathrm{km}^{2}$ \\
\hline
\end{tabular}




\section{Description of the Area}

The Houston district, as used in this report, consists of all of Harris, Waller, and Fort Bend Counties and parts of Galveston, Montgomery, Brazoria, Chambers, and Liberty Counties (fig. 1). The area of the district is approximately 6,600 square miles $(17,100$ square kilometers).

Except for a small area in Montgomery and Waller Counties, the land surface is nearly flat and featureless; the only significant relief is in the valleys of the streams. The land is generally treeless in the rural areas from Houston southeast to Galveston.

The climate of the Houston district is characterized by mild winters and hot summers. The lowest temperature recorded at Houston was $15^{\circ} \mathrm{F}$ $\left(-9.5^{\circ} \mathrm{C}\right)$ and the maximum temperature was $108^{\circ} \mathrm{F}\left(42^{\circ} \mathrm{C}\right)$. The mean annual temperature is $69.2^{\circ} \mathrm{F}\left(20.6^{\circ} \mathrm{C}\right)$. The 30 -year average $(1931-60)$ rainfall at Houston was 45.95 inches ( 116.7 centimeters); monthly rainfall is distributed uniformly throughout the year. 
The Houston district has a large and diversified industrial economy, but also has extensive agricultural developments. Large amounts of water are used by industry for processing and cooling purposes and by rice and cotton growers for irrigation. The rapid growth and development of the districtare due in part to the availability of large amounts of inexpensive ground-water supplies. The locations of the major pumping areas are shown on figure 2 .

\section{Previous Studies}

Among the more comprehensive earlier reports describing the geology and hydrology of the Houston district is the report by Lang and others (1950). Pettit and Winslow (1957) summarized the geology and groundwater resources of Galveston County. The relation of salt water to fresh ground water in Harris County was discussed by Winslow and others (1957). Land-surface subsidence and its relation to the withdrawal of ground water in the Houston-Galveston area was first reported by Winslow and Doye1 (1954) and later by Gabrysch (1969).

Previous ground-water investigations were made in Waller County (Wilson, 1967); Liberty County (Anders and others, 1968); Montgomery County (Popkin, 1971); Fort Bend County (Wesselman, 1972); Brazoria County (Sandeen and Wesselman, 1973); and Chambers County (Wesselman, 1971). These studies provided relatively recent data on the ground-water resources and ground-water development in most of the Houston district exclusive of Harris and Galveston Counties. 
A report containing data on ground-water withdrawals and water-level declines in Galveston and harris Counties was prepared by Gabrysch (1972), and the role of ground water in the development of the water system for the city of Fouston was described in reports by Turner, Collie and Braden, Inc. $(1966,1972)$.

A report by fiood and Gabrysch (1965) describes the results of the first analog-model study of ground-water hydrology in the Houston district. The usefulness of the first analog model was limited because the simulations required that the aquifers be operated independently of each other and because the results of pumping in the western part of the area could not be simulated. Evaluation of the performance of the first model indicated that improvement in aquifer designation was needed and that the transmissivity of the aquifers and vertical leakage between the aquifers were not adequately modeled.

\section{Acknowledgments}

The author expresses his appreciation to Mr. D. E. VanBuskirk of the city of Houston Water Department and to the well owners and drillers who supplied pertinent information for this study. The aquifers in the district were mapped by John Wesselman, U.S. Geological Survey, and the model was designed and constructed by William Bruns, U.S. Geological Survey. 


\section{GEOHYDROLOGY}

The geologic formations from which most of the ground water is pumped in the Houston district are composed of sedimentary deposits of gravel, sand, silt, and clay. The formations, from oldest to youngest, that form important hydrologic units are: The Catahoula Sandstone and Fleming Formation of Miocene age; the Goliad Sand of Pliocene age; the Willis Sand, Bentley and Montgomery Formations, and Beaumont Clay of Pleistocene age; and alluvium of Quatemary age (table 1). Correlation of the hydrologic units from northern Montgomery County to the Gulf of Mexico is shown by the chart on figure 3.

With exception of the alluvium and the Goliad Sand, the formations crop out in belts that are nearly parallel to the shoreline of the Gulf of Mexico. The younger formations crop out nearer the Gulf and the older ones farther inland. All the formations thicken downdip so that the older formations dip more steeply than the younger ones. Locally, however, the occurrence of salt domes and faults may cause reversals of the regional $\because-$ dip and thickening or thinning of individual beds.

Salt domes are cylindrical structures resulting from the upward movement of salt masses that are probably of Mesozoic age.. In some areas, the salt domes penetrate the uppermost aquifer and nearly reach the surface. In most instances, however, the domes pierce only the lower aquifers. Groundwater circulation within the vicinity of the domes may result in salt-. water contamination. 
Table 1..-Geologic and hydrologlo units used in this report and in recent reports on nearby areas

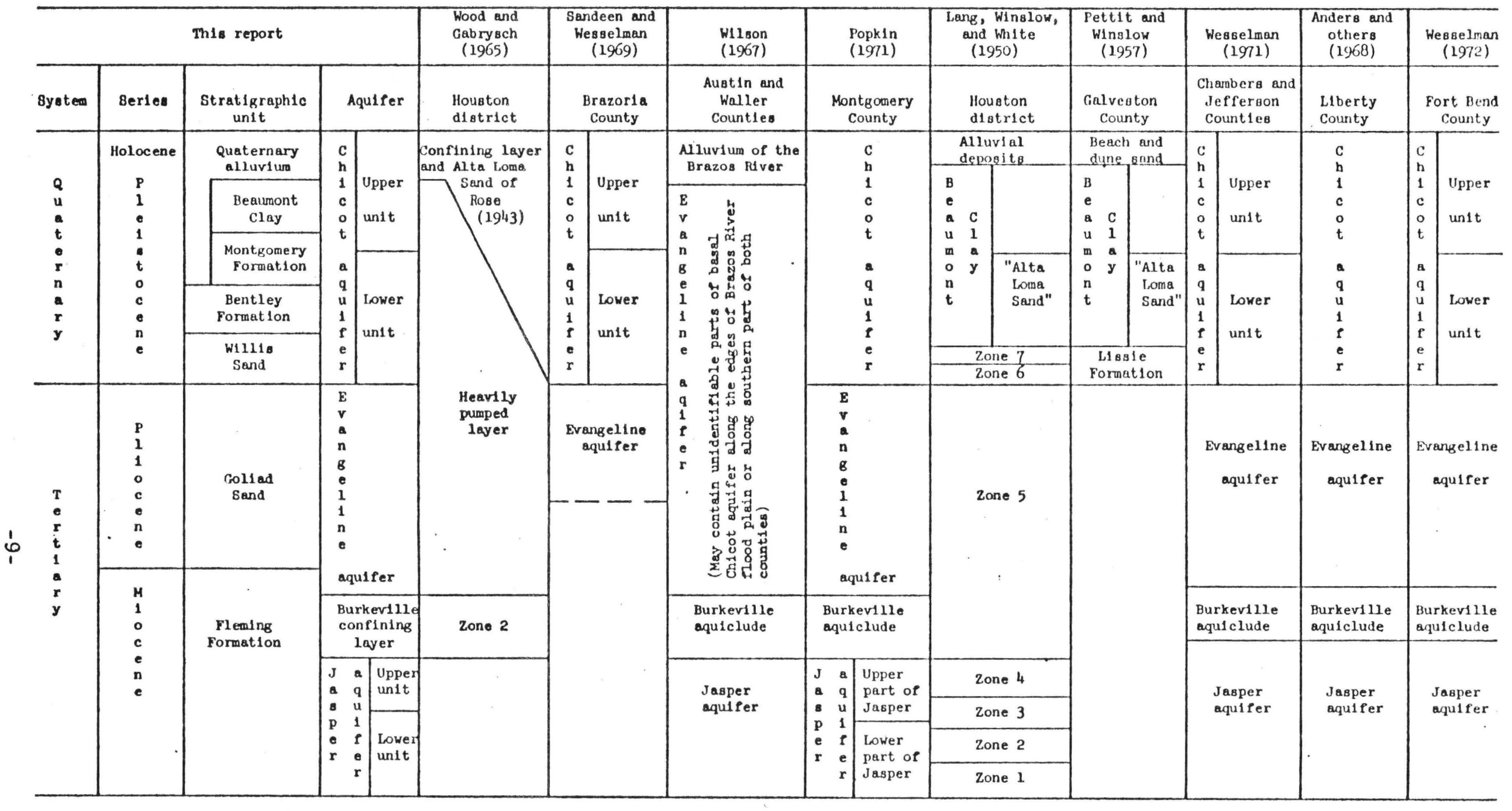


Faults in the area may have several hundred feet of displacement in the older Tertiary formations, but displacement tends to decrease upward so. that the faulting may not be apparent at the surface; generally, the geologic units containing fresh water are not displaced enough to disrupt hydraulic continuity.

\section{Description of the Water-Bearing Units \\ Chicot Aquifer}

The Chicot aquifer is composed of the Willis Sand, Bentley Formation, Montgomery Formation, Beaumont Clay, and Quaternary alluvium (table 1). The Chicot includes all deposits from the land surface to the top of the Evangeline aquifer (fig. 4).

The basis for separating the Chicot aquifer from the underlying Evangeline aquifer is primarily a difference in hydraulic conductivity, which in part causes the difference in the altitudes of the potentiometric surfaces in the two aquifers. 
In most of the Houston district, the Chicot aquifer consists of discon$1 . \quad-$

tinuous layers of sand and clay of about equal total thickness, and in some . parts of the wstrict, the aquifer can be separated into an upper and lower unit. Throuthort most of Galveston County and southeast Harris County, the basal part of the lower Chicot aquifer is formed by a massive sand section with gh hydraulic conductivity. (See fig. 4.) This sand unit, whidris is any pumped, is known locally as the Alta Loma Sand. In many previous reports, the unit is identified as the Alta Loma Sand of Rose [1943. - The term Alta Loma Sand is not often used in this report because the toric relationships are not clear.

Af the uner unit of the Chicot aquifer cannot be defined in a particularianer aquifer is said to be undifferentiated. The areal extent of upperionit roughly corresponds to the areal extent of the Beaumont Clay The The in which the aquifer cannot be differentiated into units are osty, the northern part of the district (fig.5).

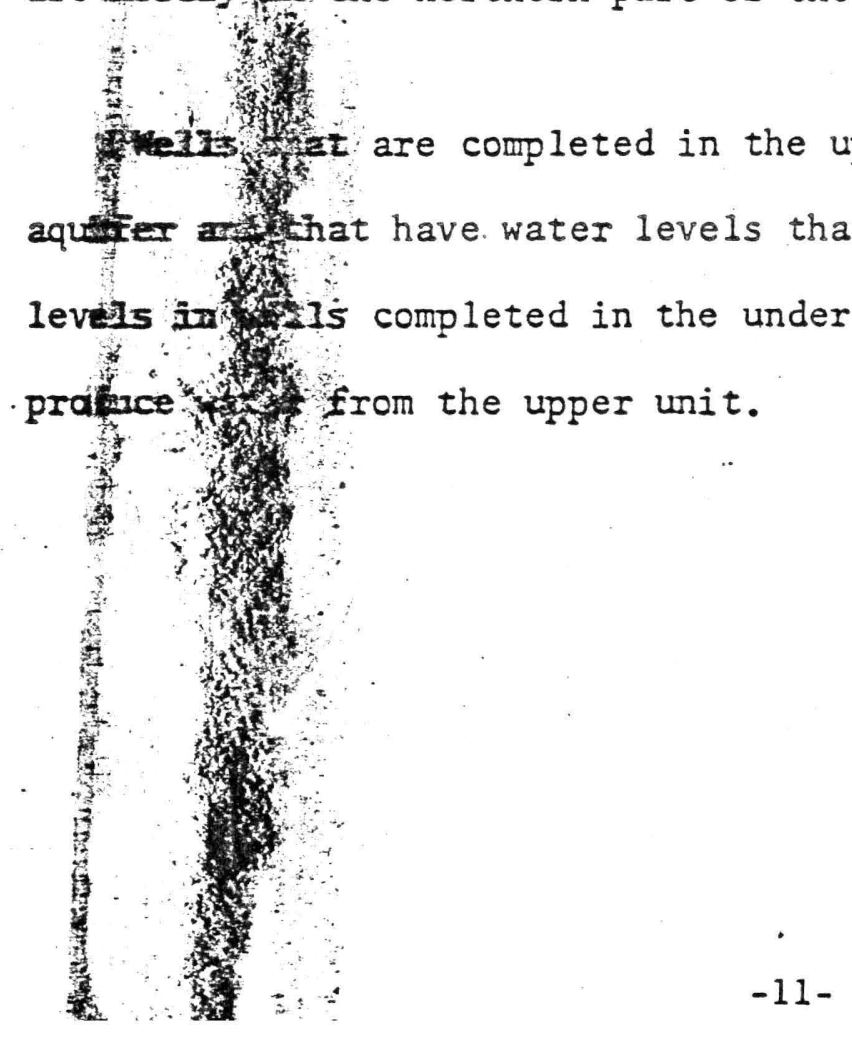


The transmissivity of the Chicot aquifer ranges from zero to about $20,000 \mathrm{ft}^{2} /$ day (feet squared per day) or $1,858 \mathrm{~m}^{2} /$ day (meters squared per day). The storage coefficient ranges from 0.0004 to 0.20 (fig. 6). The larger values of the storage coefficient occurs in the northern part of the district where the aquifer is partly or totally under water-table conditions.

\section{Evangeline Aquifer}

The Evangeline aquifer, which is the most important source of fresh ground water in the Houston metropolitan area, consists of layers of sand and clay that are present throughout the district except where the unit is pierced by salt domes (fig. 7). The aquifer is underlain by the Burkeville confining layer.

The transmissivity of the Evangeline aquifer ranges from less than $5,000 \mathrm{ft}^{2} /$ day $\left(460 \mathrm{~m}^{2} /\right.$ day) to about $15,000 \mathrm{ft}^{2} /$ day $\left(1,400 \mathrm{~m}^{2} /\right.$ day). (See fig. 8.) In general, the horizontal hydraulic conductivity of the Evangeline aquifer is less than the horizontal hydraulic conductivity of the Chicot aquifer, but because the Evangeline is generally thicker than the Chicot, it is generally more transmissive. 
The storage coefficient of the Evangeline ranges from about 0.0005 to 0.0002 where it occurs under artesian conditions; in the outcrop area, where the aquifer is under water-table conditions, the storage coefficient ranges from greater than 0.002 to 0.20 .

\section{Burkeville Confining Layer}

The Burkeville confining layer, which in the outcrop area is in the upper part of the Fleming Formation of Tertiary age, is composed mostly of clay but contains some layers of sand. The Burkeville restricts the flow of water except where it is pierced by salt domes and in the northeastern part of the district where it contains many water-yielding sand layers. The Burkeville is underlain by the Jasper aquifer.

Declines in the Altitudes of the Potentiometric Surfaces

Records of ground-water withdrawals in the Houston district date back to 1887 , and records exist for probably 90 percent of the total withdrawals.

Use of ground water increased slowly until about 1937, when rapid industrialization increased the rate of use. In 1955, surface water from the San Jacinto River (Lake Houston) became available, and the use of groune water remained relatively constant until 1962. From 1962 to 1970, the use of ground water increased to about $575 \mathrm{mgd}$ (million gallons per day) or 2.2 million $\mathrm{m}^{3} /$ day (cubic meters per day). The historic withdrawals of ground water for 1890-1970 and the predicted withdrawals for 1971-80 are shown on figure 9 . 
The pumping of large quantities of ground water has caused large declines in the altitudes of the potentiometric surfaces in the aquifers, except in the upper unit of the Chicot. The declines from 1890 to 1953, from 1890 to 1960, and from 1890 to 1970 in the lower unit of the Chicot aquifers and in the Chicot aquifer undifferentiated are shown on figures 10, 11, and 12. Figures 13, 14, and 15 show the decline of the altitude of the potentiometric surface in the Evangeline aquifer for the same periods.

By 1970 , the altitude of the potentiometric surface had declined a maximum of about 330 feet (100 meters) in the lower unit of the Chicot aquifer and Chicot aquifer undifferentiated and about 430 feet (130 meters) in the Evangeline aquifer.

Not enough data are available to map the decline of the altitude of the potentiometric surface in the upper unit of the Chicot aquifer.

\section{Houston Area}

Nearly all the ground water pumped in the Houston area (fig. 2) is from wells screened in the Evangeline or Chicot aquifers, and many of the wells are screened in both aquifers. (The reader should note that the Houston area is only a part of the Houston district.) The declines of water levels in wells screened in each of the aquifers are shown on figure 16. Locations of the wells are shown on figure 2 . 
Declines in the Evangeline aquifer and the lower unit of the Chicot aquifer have been the greatest. The upper unit of the Chicot is relatively undeveloped; therefore, the decline of water levels shown on figure 16 for the upper unit of the Chicot is due in part to the discharge of water to the lower unit.

\section{Pasadena Area}

The Pasadena area is an industrialized area east of the Houston area and mostly west of the San Jacinto River (fig. 2). Most of the ground water pumped in this area is from the Evangeline aquifer, but a considerable amount is withdrawn from the lower unit of the Chicot in the southeastern part of the area. A small and mostly unrecorded amount is pumped from the upper unit of the Chicot.

Figure 17 shows the decline of water levels in three wells, each of which is screened in a different water-bearing unit. The decline of the altitude of the potentiometric surface in the upper unit of the Chicot is not as great as the decline in either the Evangeline or the lower unit of the Chicot. The decline in the upper unit of the Chicot is attributed to discharge to the lower unit and to a small amount of pumping. 
Katy Area

The Katy area is an agricultural area west of the Houston area and includes the northern and western parts of Harris County, about half of Waller County, and northern Fort Bend County (fig. 2).

Ground water is used exclusively in the Katy area and most of it is used for rice irrigation. Most of the water pumped is from the lower unit of the Chicot aquifer, the Chicot aquifer undifferentiated, and the Evangeline aquifer. In the northern part of Fort Bend County, along the Brazos River, some water is pumped from the alluvium, which is a part of the upper unit of the Chicot aquifer.

Figure 18 shows the water-level declines in well LJ-65-04-507, completed in the Chicot aquifer undifferentiated and in well LJ-65-04-607, completed in the Evangeline aquifer. Declines are greater in wells screened in the Evangeline aquifer than in wells screened in the Chicot aquifer undifferentiated.

\section{Baytown-La Porte Area}

The Baytown-La Porte area extends eastward from the Pasadena area to the Chambers County line (fig. 2). It is primarily an industrial area, in which most of the ground water used is pumped from the lower unit of the Chicot aquifer. 
Figure 19 shows the water-level declines in well LJ-65-24-606, screened in the Evangeline aquifer and in well LJ-65-24-501, screened in the lower unit of the Chicot aquifer. Although most withdrawals in the area are from the lower unit of the Chicot, the rate of decline in the Evangeline is nearly as large as the decline in the lower unit of the Chicot.

The altitude of the potentiometric surface in the Evangeline aquifer in the Baytown-La Porte area is declining as a result of three factors: Large withdrawals from the Evangeline in the adjacent Pasadena area; upward movement of water into the Chicot aquifer; and small withdrawals from the Evangeline aquifer within the area. The effect of the local withdrawals is small compared to the effect of the other two factors.

\section{NASA Area}

The NASA area (fig. 2), which is bounded on the north by the BaytownLa Porte area and on the west by the Pasadena and Houston areas, is an industrial-urban area that is centered around the Johnson Space Center of the National Aeronautics and Space Administration (NASA). Nearly all the ground water used in this area is pumped from the lower unit of the Chicot aquifer. 
Figure 20 shows the water-level decline in well W-65-24-708 screened in the lower unit of the Chicot. Although withdrawals are not large in comparison to withdrawals in other areas, the water level is declining rapidly owing to the spreading of the large cone of depression centered in the Pasadena area.

\section{Texas City Area}

The Texas City area is in Galveston County and includes Texas City and La Marque which adjoins Texas City (fig. 2). Nearly all the groundwater withdrawals are from the lower unit of the Chicot aquifer.

Figure 21 shows the water-level fluctuations in well KH-64-33-805, which is screened in the lower unit of the Chicot. The recovery of the water level during 1948-50 reflects a decrease in pumping. The gradual decline from 1958-70 is due to increased pumping and, to a lesser degree, to pumping in the nearby Alta Loma area.

\section{Alta Loma Area}

The Alta Loma area, in west-central Galveston County, includes the well fields for Alta Loma and Galveston (fig. 2)。 All the withdrawals are from the lower unit of the Chicot aquifer. 
Figure 21 shows the water levels in a test well in the Galveston well field. Water levels have declined at a nearly constant rate of about 2.4 feet ( 0.73 meter) per year since 1944 because of continuous pumping in the area.

\section{Salt-Water Encroachment}

Ground-water pumping has changed the predevelopment conditions of equilibrium in nearly all the Houston district. The lowering of the altitudes of the potentiometric surfaces has reversed the regional hydraulic gradient so that the interface between fresh and saline ground water is now moving toward the centers of the cones of depression. The rate of movement of the interface between the salt water and fresh water was estimated by Winslow and others (1957, p. 395-397) to be a few hundred feet per year. The present (1974) location of the salt-water interface is not well known, and the available data are insufficient to determine accurately the rate of lateral movement.

Salt water also occurs in $10 \mathrm{cal}$ areas in the vicinity of salt domes. For example, water with a dissolved-solids concentration of more than 1,000 mg/l (milligrams per liter) occurs near all salt domes that penetrate the Chicot aquifer in Fort Bend County (Wesselman, 1972, p. 27). 
As water is pumped from a confined aquifer, the decrease in artesian pressure results in compression of the water-bearing material. Most of the water released from storage is derived from compaction of the finegrained sediments, which in turn results in subsidence of the land surface. Compaction of clay beds may also occur in a water-table aquifer with a declining hydrostatic head. The compaction is due to the increased load that results from the loss of buoyancy of the aquifer material when the water level is lowered.

The rate and amount of compaction of a clay bed is dependent on the loading, the hydraulic conductivity of the clay, previous compaction, length of the drainage path, and the character of the clay. In general, clays compact more rapidly if the pressure, causing compaction is greater than previous pressure. This previous pressure or loading is termed the "preconsolidation load."

The factors that affect the compaction of clays are complex and are not completely understood; however, parameters such as the coefficient of compressibility and the compression index, which are determined from consolidation tests in a laboratory, are used to define the compressibility of the clay. 
Figure 22 shows the percentage of subsidence resulting from compaction of clays with depths as determined in a well on the campus of the University of Houston. Loading was determined from water levels in wells, and the compaction characteristics of the clays were determined by Wolfskill (1960) from analyses of cores from test well LJ-65-22-103 in the Houston area.

The calculations indicated that most of the compaction occurs above the Evangeline aquifer. In much of the district and especially north of Houston, however, compaction of clay layers within the Evangeline aquifer may exceed the amount of compaction above the Evangeline, largely because of the decrease of clay thickness within the Chicot aquifer north of Houston. 
Gabrysch (1969) related land-surface subsidence to the decline in the altitude of the potentiometric surface and to the percentage of clay above the bottom of the screened sections in wells (fig. 23). The subsidence ratio, which can be considered as a mininum storage coefficient of the clay beds, ranged from about 0.005 to about 0.03 . The relationship did not include time as a variable; however, it clearly showed that subsidence was a function of the percentage of clay. The approximate land-surface subsidence in most of the district from 1906-43 is shown on figure 24, and subsidence during 1943-64 is shown on figure 25 .

Figure 24 shows the large amount of subsidence at Texas City that resulted from artesian-pressure declines associated with the high rate of industrial pumping from 1935 to 1943. The rate of subsidence decreased at Texas City after 1945 when rates of artesian-pressure decline began to stabilize. In 1948, when the recovery of pressures began (fig. 21), the rate of subsidence was markedly reduced. 
Recently, large artesian-pressure declines resulting from heavy pumping have caused rapid land-surface subsidence from Houston to Baytown. Subsidence in the district is subjecting an increasingly large area along Galveston Bay and the Houston Ship Channel to flooding from high tides.

Statistical analysis of subsidence data from a compaction recorder at wel1 LJ-65-32-401 in the NASA area indicates that the lag between the time of artesian-pressure decline and the time of the maximum rate of clay compaction from land surface to a depth of 750 feet (229 meters), as recorded at the well, is less than 6 months.

The volume of water derived from the compaction of clay is very nearly equal to the volume of subsidence in the Houston district because nearly all subsidence is related to ground-water pumping from the Chicot and Evangeline aquifers. Winslow and Wood (1959, p. 1034) stated that approximately 22 percent of the ground water pumped was derived from clay compaction.

A list of the approximate percentages of water derived from clay compaction for different periods of time is given in table 2. The compaction ratio, which is the volume of land-surface subsidence to the volume of water pumped, is also given in table 2 . The ratio indicates that about one-fifth of the water pumped in the district is derived from clay compaction. 
Table 2.--Approximate volume of water derived from clay compaction in the Houston district

\begin{tabular}{|c|c|c|c|}
\hline $\begin{array}{c}\text { Interval } \\
\text { I/ } \\
\text { (1) } \\
\end{array}$ & $\begin{array}{c}\text { Clay } 2 / \\
\text { compaction } \\
\left(\mathrm{ft}^{\bar{j}} \times 10^{10}\right) \\
(2)\end{array}$ & $\begin{array}{c}\text { Total ground } 3 / \\
\text { water pumped } \\
\left(\mathrm{ft}^{3} \times 10^{10}\right) \\
(3)\end{array}$ & $\begin{array}{c}\text { Compaction } \\
\text { ratio 4/ } \\
\text { (4) }\end{array}$ \\
\hline $1906-43$ & 2.32 & 11.72 & 0.20 \\
\hline $1943-54$ & 2.69 & 15.70 & .17 \\
\hline $1954-59$ & 1.93 & 8.77 & .22 \\
\hline $1959-64$ & 1.96 & 9.21 & .21 \\
\hline $1890-1964$ & a/ 8.90 & 46.7 & .19 \\
\hline $1943-51$ & -- & -- & b/ .17 \\
\hline $1943-59$ & -- & -- & c/ .22 \\
\hline
\end{tabular}

1/ From midyear to midyear except for the year 1890 .

2/ Volume of land-surface subsidence determined from maps.

3/ Total pumpage during the interval, exclusive of water pumped from upper unit of the Chicot aquifer.

4) Ratio of column 2 to column 3.

a/ Assumes no subsidence prior to 1906 .

b/ Reported by Winslow and Doyel (1954).

cf Reported by Winslow and Wood (1959). 


\section{ANALOG-YODEL STUDIES}

\section{Theory of the Electric Analog Yodel}

The unsteady confined flow of water in a uniform porous medium in three dimensions is defined by the partial differential equation (Jacob, 1950, p. 333).

$$
\frac{\partial^{2} h}{\partial x^{2}}+\frac{\partial^{2} h}{\partial y^{2}}+\frac{\partial^{2} h}{\partial z^{2}}=\frac{S}{T} \frac{\partial h}{\partial t}
$$

where $h=$ head at any point whose coordinates are $x$ and $y$,

$$
\begin{aligned}
& t=\text { time, } \\
& T=\text { transmissivity, and } \\
& S=\text { storage coefficient } .
\end{aligned}
$$

The similar equation for a three-dimensional diffusion field in electricity (Karplus, 1958, p. 33) is: :

$$
\frac{\partial^{2} V}{\partial x^{2}}+\frac{\partial^{2} V}{\partial y^{2}}=\frac{\partial^{2} V}{\partial z^{2}}=R C \frac{\partial V}{\partial t}
$$

where $V=$ voltage, at any point whose coordinates are ' $x$ and $y$,

$$
\begin{aligned}
& \mathrm{R}=\text { resistance, and } \\
& \mathrm{C}=\text { capacitance. }
\end{aligned}
$$

The equations are of similar form, indicating that the flow. of electricity is analogous to the flow of water in a porous medium. Voltage is analogous to head, resistance is analogous to the reciprocal of transmissivity, and capacitance is analogous to the storage coefficient. 
These relations, combined with Ohm's, Kirchhoff's and Darcy's laws and dimensional-analysis techniques are used to determine the specific analog relationships. Walton and Prickett (1963), Patten (1965), Jorgensen and Ackroyd (1973), and many others have described these relationships, which are used to design the specific elements of the analog model.

\section{Description of the Model}

The analog model is made of arrays of resistors, capacitors, and current-limiting diodes mounted on a masonite peg board as shown on figure 26. Figure 27 is a schematic diagram of a simple single-layer analog model and its operating components.

Errors arising from modeling the continuous ground-water medium with an array of resistors can be minimized by using as small a grid spacing as possible.

Electrical inputs are provided by a power source consisting of pulse and waveform generators. The electrical response of the model with time is observed and measured by the use of an oscilloscope. (See fig. 27.) Measurements of voltage, current, resistance, and capacitance are then converted to hydrologic quantities by using conversion factors.

The Houston model is similar to the model shown on figure 27 except that is a two-layered model and has additional electrical elements used to simulate effective vertical hydraulic conductivity and storage due to clay compaction. Diagrams of the electrical circuits that were used to model the ground-water system are shown on figure 28 . 
The resistors marked $R_{l}$ in figure 28 are used to model the resistance to water moveneat in the vertical direction. The resistors marked $R_{2}$ are used to model tive resistance to water movement in the lateral direction. is.

Theseresistors $\left(R_{1}\right.$ and $\left.R_{2}\right)$ model the reciprocal of effective vertical hydrawlic condictivity. The capacitors marked $C_{1}$ are

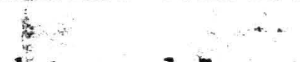

The switches are electronically activated to allow the capacitors to model the denease of water stored in the easily compressed clays during i 5 periods of decreasing artesian pressure, but not to allow the quantity - of water stored to increase during periods of increasing artesian pressure. Thus swites enable the modeling of the easily compressible clay in the imelast $=$ state. The capacitor marked $C_{2}$ has a large capacitance and is used to monel the large water-table storage coefficient. The capacitor is

markef $C_{3}$ as a small capacitance and is used to model the small storage capaty of aquifer under artesian conditions. The resistors marked $\mathrm{R}_{\mathrm{CW}} \mathrm{R}_{\mathrm{E} \text { are }}$ used to model wells pumping from the Chicot aquifer and the Evarieline paifer respectively.

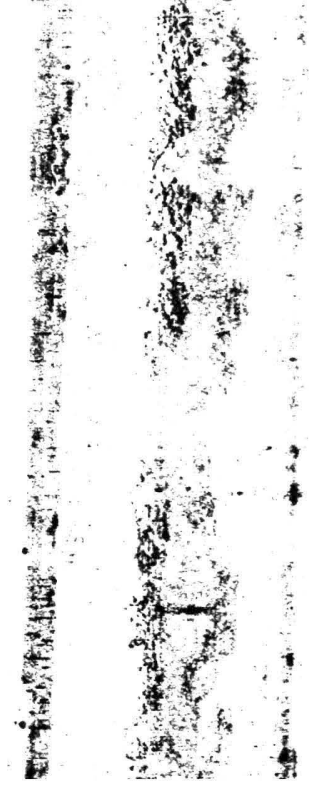


The model, exclusive of the equipment required for input and "read out," consists of approximately 65,000 electrical elements and several miles of conductor wire. An area of 9,100 square miles (23,570 square kilometers), which is larger than the Houston district, was modeled to minimize the boundary effects. The grid spacing used was 1 square mile $(2.590$ square kilometers).

\section{Hydrologic Properties and Parameters Modeled}

\section{Ground-Water Withdrawals}

The duration of ground-water pumping was divided into six periods: $1890-1930,1931-46,1947-53,1954-60,1961-64$, and 1965-70. The records of pumping were considered to be good but some pumping for irrigation was not recorded. The distribution of withdrawals by aquifer was based on the proportion of the well screens that occurred in each aquifer. This method of distribution is satisfactory because the declines in artesian pressures and transmissivities are similar in both aquifers. The similarities of the declines in artesian pressures result partly from the nearly equal withdrawals from each aquifer and partly because the aquifers are in hydraulic continuity. 
Withdrawals from the upper unit of the Chicot aquifer were not modeled because they are of minor importance in the district and because not enough data are available to construct maps showing the change in the altitude of the potentiometric surface.

\section{Aquifer Transmissivity}

Estimates of transmissivity values were determined from aquifer-test data by using the Theis equation and the modified Hantush equation as they are outlined by Lohman (1972, p. 15-19, p. 32-34). In the development of the Theis equation, it is assumed that no water is supplied to the aquifer by vertical leakage or from clay storage. The modified Hantush method includes sources of water from vertical leakage and from clay storage. In the Houston area, evidence of vertical leakage and clay compaction is documented; therefore, transmissivity values obtained by using the modified Hantush equation seem more applicable. However, the development of this method is based on conditions of a single aquifer with one or two confining layers. Values of transmissivity obtained by use of the Theis equation were generally 1.25 to 4.0 times larger than the values obtained by using the modified Hantush equation. 
Nearly all the wells tested had multiple screens, but did not screen the entire aquifer section; therefore, a method to correct for partial penetration of wells (Sternberg, 1973, p. 5-7) was used in determining transmissivity. Because this method was applicable only to conditions of simple partial penetration, the transmissivity values were unreasonably large. An empirical relation based on a correlation of transmissivity and percentage penetration was developed to correct transmissivity values. In general, the correlation indicated that wells with partial penetration greater than 60 percent had nearly the same specific capacity as wells having partial penetration of 90 percent.

Because no equations have been developed to describe the complex aquifer-confining layer system characteristics of the Houston district, it should be noted that the values of transmissivities obtained from aquifertest data by using the commonly published equation are only approximations. The transmissivity values obtained from analysis of aquifer-test data were used to define the range of rational transmissivity values to be tested in the model. 


\section{Aquifer Storage Coefficient}

Estimates of storage coefficients in the artesian parts of the aquifers were obtained by the use of the Theis equation and the modified Hantush equation. Storage coefficients as determined by the use of the modified Hantush equation are lower, but are in general agreement with values obtained by the use of the Theis equation. The differences are of small significance to the hydrologic system because the artesian storage coefficient is of such a small magnitude that the amount of water obtained by the reduction of artesian pressure is only a small part of the total water available in the ground-water system.

The storage coefficient of the parts of the aquifers under watertable or partly water-table conditions was determined by model calibration.

\section{Storage Coefficient of Clays}

The storage coefficients for the clay beds were included in the model because the clay beds, which are easily compressed, yield significant amounts of water. The estimates were based on consolidation tests of clay samples, on multiple linear-analysis techniques, and by use of the empirical relation shown on figure 23. Al1 methods gave similar results, but data presently (1974) being collected indicate that clay-storage coefficients as large as 0.05 may exist within the modeled area. The storage coefficients of the clays as modeled ranged from 0.005 to 0.02 . 
All clay compaction was modeled in that part of the section extending from ground level to the centerline of the lower unit of the Chicot or the Chicot undifferentiated, (see capacitors labeled $C_{1}$ in figure 28). The approximation causes little error at Houston (fig. 22), but at other locations, such as north of Houston where the thickness of the clay layers in the Chicot aquifer is small, most of the clay compaction may occur in the Evangeline aquifer.

$$
\text { Quantity of Water from Clay Storage }
$$

- The quantity of water derived from clay compaction (fig. 29 and

table 2), which is a function of the diffusivity of the clay layers and the applied load, was determined by calculating the volume of land-surface subsidence, which is very nearly equal to the volume of water released by clay compaction. For example, by 1964 about $9 \times 10^{10} \mathrm{ft}^{3}\left(0.25 \times 10^{10} \mathrm{~m}^{3}\right)$ of water had been released by the clays. 
Vertical Hydraulic Conductivity and Vertical Leakage

Three estimates of effective vertical hydraulic conductivities of the clay beds were made for the following assumptions: (1) The clay layers in a section are one thick and continuous bed; (2) the clay layers in a clay section are separate and extend over a large area; (3) the clay layers in a clay section are discontinuous in a highly anisotropic aquifer. The range in values of hydraulic conductivity under these assumptions is from $10^{-7} \mathrm{ft} /$ day (foot per day) or $0.3 \times 10^{-7} \mathrm{~m} /$ day (meter per day) to $1 \mathrm{ft} /$ day $(0.3 \mathrm{~m} /$ day $)$. The assumptions used for the three estimates above do not fit the conditions in the Houston district, but the estimates define the limits of the true vertical hydraulic conductivity.

An estimate of vertical hydraulic conductivity was also made from analysis of temperature profiles in small-diameter wells M. L. Sorey, written commun., 1971.). The estimated value by this method was $0.07 \mathrm{ft} / \mathrm{day}$ $(0.02 \mathrm{~m} /$ day $)$. A numerical method to determine the steady-state accretion rate indicated a hydraulic conductivity value of approximately $10^{-5} \mathrm{ft} /$ day $\left(0.3 \times 10^{-5} \mathrm{~m} /\right.$ day $)$. Because of the large difference in the estimates of the effective vertical hydraulic conductivity, the values used in the model were determined by calibration.

An estimate of the quantity of water entering the aquifer from vertical leakage was made by use of a steady-state analysis of flow in the aquifers. The analysis indicated that the leakage occurred in that part of the aquifers between ground level and the centerline of the undifferentiated or lower unit of the Chicot. The analysis was made of only the Houston area; therefore, it excluded vertical leakage from irrigation return. 
Declines in the Altitudes of the Potentiometric Surfaces Maps showing declines in the altitudes of the potentiometric surfaces were made for each unit for the periods 1890-195j, 1890-1960, and 1890-1970. (See figures 10-15.) Because the aquifers are anisotropic and because different sand layers within the same aquifer have different potentiometric surfaces, the maps were constructed to show the approximate altitude of the potentiometric surface in the aquifer at its centerline. Therefore, not all wells screened in a single aquifer will have the same depth to water, even if they are within a few feet of each other if they are screened at different depths. However, most single-screened wells in an area will have depths to water of about plus or minus 10 feet ( 3 meters) of the depths shown on the maps showing the declines in the altitudes of the potentiometric surfaces. 


\section{Calibration of the Model and Results}

The model was calibrated by simulating hydrologic conditions and comparing the results obtained from the model with those obtained from field measurements in the hydrologic system. Where the comparison of the measured hydrologic conditions and the analog results was poor, the model was modified and tested again. This process of calibration was continued until the model accurately simulated the measured responses of the hydrologic system.

In particular, the model was verified for declines in the altitudes of the potentiometric surfaces in the Evangeline aquifer, the lower unit of the Chicot aquifer, and the Chicot aquifer undifferentiated in 1953, 1960, and 1970. In addition, the model was verified for the volume of water derived from clay corpaction. The simulated and measured declines in the altitudes of the potentiometric surfaces are shown on figures 1015. The simulated and calculated volumes of water derived from clay compaction are shown on figure 29.

Some of the important hydrologic relations that were indicated by the calibration procedure and which have been used in all problem solutions are as follows:

1. A large part of the Chicot aquifer undifferentiated in the north and northwest parts of the district is at least partly under water-table conditions. 
2. Vertical leakage of water, exclusive of irrigation return, from the land surface to the centerline of the lower unit of the Chicot aquifer and the Chicot aquifer undifferentiated is an important element of the hydrologic budget (table 3 ).

3. The transmissivity values as determined by model calibration (figs. 6 and 8 ) are about 70 percent of the values obtained from the Theis equation alone, about 50 percent of the values used by Wood and Gabrysch (1965), and about 50 percent of the values determined by applying the empirical correction to the results of analysis by the Theis equation.

4. Large quantities of water are probably exchanged between the aquifers through irrigation wells and other wells in the Katy area because a reduction in pumpage from the Evangeline aquifer in that area was required for calibration. The exchange probably occurs through wells at times when the wells are not being pumped.

5. About 20 to 30 percent of the ground water pumped for irrigation in the Katy area returns to the Chicot aquifer undifferentiated.

The hydrologic budget for 1953, 1960, and 1970 is given in table 3 . The characteristics modeled for the lower unit of the Chicot aquifer and the Chicot aquifer undifferentiated are shown on figures 5 and 6 . The characteristics for the Evangeline aquifer are shown on figure 8 . The characteristics as shown on figures 6 and 8 have been used in all problem solutions regarding water-level declines. 
Table 3.--Hydrologic budget used to verify the analog model

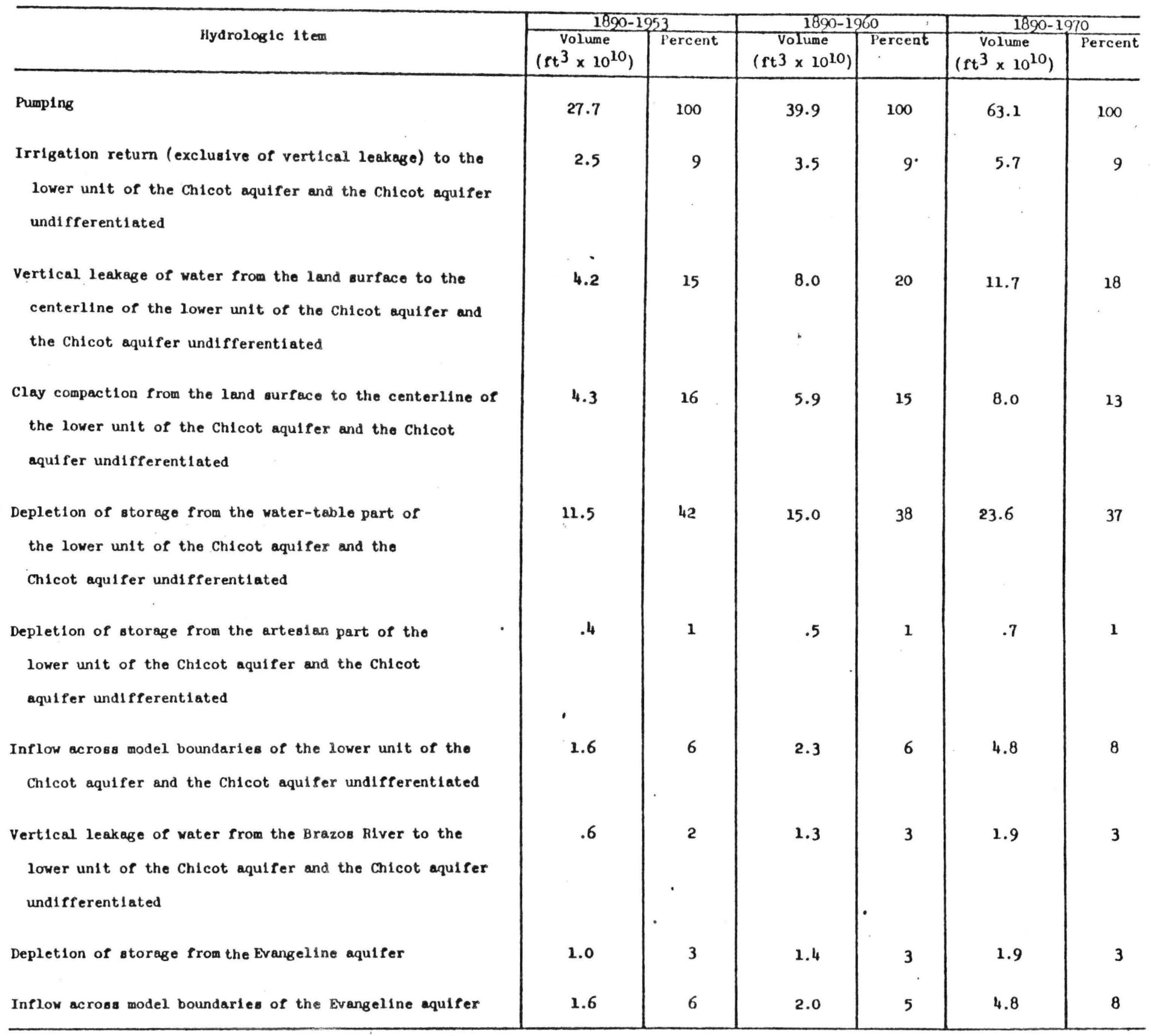


The inflow of ground water across the boundaries increased from 12 percent for 1890-1953 to 16 percent for 1890-1970.

The increased inflow resulted from an increase in the area of the cones of depression. The decrease in the simulated percentage of water derived from clay compaction is due in part to the increase in inflow across the boundaries and in part to the modeling of low values for the storage coefficients of the clay beds.

Model Sensitivity

Effective vertical hydraulic conductivities were tested over a wide range of values. Because vertical leakage is a function of effective vertical hydraulic conductivity and the change in stress (change in the altitude of the potentiometric surface), the model was tested by keeping stress for the 1890-1970 pumping period approximately constant and changing only the effective vertical hydraulic conductivity (vertical resistors). The sensitivity of the model to effective vertical hydraulic conductivity is shown on figure 30 . 
The effective vertical hydraulic conductivity for the section between ground level and the centerline of the lower unit of the Chicot aquifer and Chicot aquifer undifferentiated was $0.00065 \mathrm{ft} /$ day $(0.00020 \mathrm{~m} /$ day $)$. The effective vertical hydraulic conductivity for the section between the centerlines of the two aquifers was $0.0092 \mathrm{ft} /$ day $(0.0028 \mathrm{~m} /$ day $)$. The difference in conductivity is due partly to the fact that all clay compaction was modeled in the upper layer. Recent information also indicates that the storage coefficient of the clays may be larger than the value that was modeled in the upper layer.

The model was tested for sensitivity to variations in aquifer-storage coefficients, and except for the areas of water-table storage, the model is insensitive to variations in storage coefficients over a range of plus or minus 5x. The model was also tested for sensitivity to changes in transmissivity over a range of $I X$ to $2 X$, and was found to be very sensitive.

Boundary conditions were relatively unimportant until the end of the simulated 1970 period, when the cones of depression reached the edges of the modeled area. The model is sensitive to all simulations of boundary conditions after 1970.

The model was tested for sensitivity with and without clay storage and vertical leakage for conditions simulating the recovery of water levels. The model was relatively insensitive to this condition because the maximum difference of potentiometric-head decline was less than 10 percent in the deepest parts of the cones of depression. 


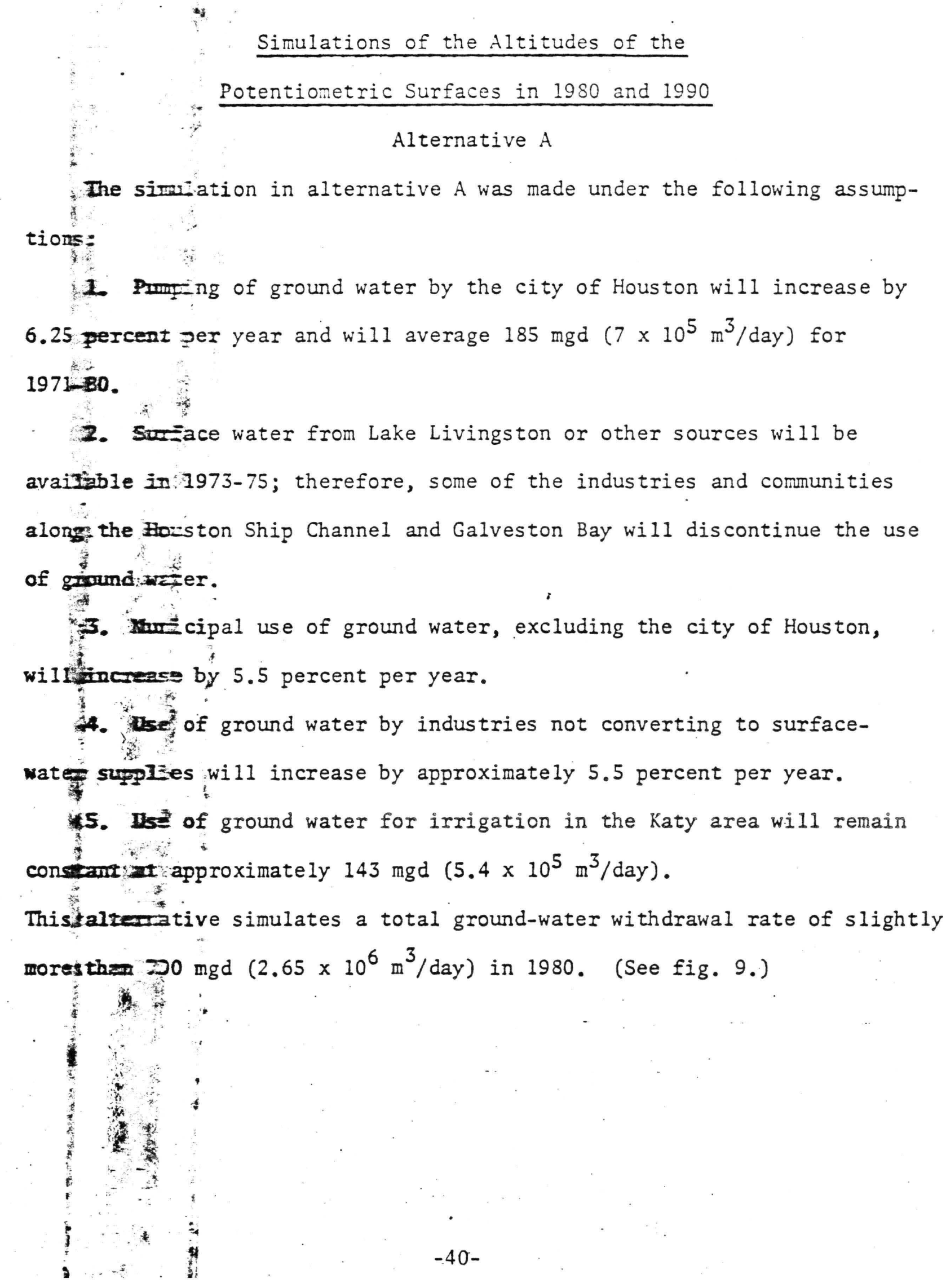


Figures 31 and 32 show the simulated declines in the altitude of the potentiometric surfaces of each aquifer for 1890-1980. The decline in the Chicot aquifer, resulting from pumping during 1971-80 is about 25 feet ( 7.6 meters) at the center of the cone; during this period, the center of the cone of depression shifted slightly to the west (figs. 11 and 31 ).

The center of the cone of depression in the Evangeline aquifer also shifted to the west (figs. 13 and 32). Although the maximum simulated decline for 1890-1980 is only about 20 feet ( 6 meters) more than the maximum decline for 1890-1970, the cone of depression enlarged, and additional declines of more than 100 feet ( 30 meters) occurred at some locations.

In general, if the quantity and distribution of pumping occur as simulated, the area of most active land-surface subsidence can be expected to shift outward from the centers of the cones of depression into the areas that have the maximum simulated declines in the altitudes of the potentiometric surfaces. 
Figures 33 and. 34 show the declines in the altitudes of the potentiometric surface for 1890-1990, resulting from pumping during 1890-1980 and recovery from 1981-1990. The simulation was made by electronically switching off the capacitors simulating clay storage along with the resistors simulating pumping wells at the model time of 1980. This in effect simulates water-level recovery due to a hypothetical condition of eliminating all pumping in the Houston district at 1980 and not allowing water to be recharged as storage in the clay layers. The rate at which water levels would recover if pumping were stopped is important because, in part, it controls the length of time during which subsidence and saltwater encroachment would occur after withdrawals cease.

After the end of simulated pumping in 1980, recovery began in most areas, but declines continued in some areas. Rapid recovery occurred in both aquifers in areas where they are under artesian conditions. However, in the water-table area of the Chicot aquifer undifferentiated, as shown on figure 33 recovery was slow or nonexistent. The altitude of the potentiometric surface in the Chicot aquifer undifferentiated continued to decline in parts of Montgomery County and recovered only slowly in the Katy riceirrigation area. 
The variable recovery rate resulted in a large westward shift of the center of the cone of depression for the lower unit of the Chicot aquifer and the Chicot aquifer undifferentiated. The center is in an area where the undifferentiated part of the Chicot aquifer is modeled with a watertable storage coefficient. The water-table area has a slower recovery rate than the artesian area because it takes approximately 400 times the volume of water to effect an equivalent head increase.

The difference in storage caused the center of the old cone of depression in the artesian area to recover about 260 feet ( 79 meters) after 10 years, while the new center in the water-table area had recovered only about 40 feet ( 12 meters). The same effect was reflected in declines in the altitude of the potentiometric surface in the Evangeline aquifer (fig. 34).

The results show that recovery is rapid and nearly complete in 10 years; therefore, it might be expected that the rates of land-surface subsidence and salt-water encroachment would rapidly decrease. However, saltwater encroachment would continue to some degree until all head differences had been equaled, and subsidence would continue until the artesian pressure in the clays equaled the artesian pressure in the adjacent sands.

The results imply that a large quantity of water could be pumped from wells in the water-table areas without greatly lowering the potentiometric surface and that water could be recharged to the aquifers at the.present centers of the cones of depression to effect recovery of artesian pressures. The net result would be a significant rise in the average altitude of the potentiometric surface. 
This operation, which would permit fresh ground water to be stored in the centers of the present cones of depression, would reduce salt-water encroachment and clay compaction. The same effect could be obtained by reducing withdrawals in the artesian areas to the extent that artesian pressures would recover.

\section{Altemative $B$}

Alternative A was based largely on extensions of current rates of withdrawals and allowances for the use of surface water by some of the industries along Galveston Bay. Alternative B is similar to alternative A, except that the distribution of pumping for the city of Houston has been changed in accordance with the recommendations of Tumer, Collie and Braden, Inc. (1972, table 6), consultants to the city of Houston.

The increase in the quantity of water pumped by the city of Houston in altemative $B$ is 5.4 percent or $10 \mathrm{mgd}\left(0.04 \times 10^{6} \mathrm{~m}^{3} /\right.$ day), which is slightly less than the quantity pumped in alternative A. New or expanded well fields were located around the edges of the city (figs. 35 and 36), and the quantity of water pumped by older wells inside the city was slightly reduced. A withdrawal rate of slightly less than $700 \mathrm{mgd}\left(2.65 \times 10^{6} \mathrm{~m}^{3} /\right.$ day) is presumed for 1980. 
Figures 35 and 36 show the new or expanded well fields and the declines in the altitude of the potentiometric surfaces simulated for alternative B. Because the quantity of water pumped is about equal to the quantity pumped in alternative $A$, the declines in the altitude of the potentiometric surfaces are similar.

\section{Alternative C}

The simulated decline in the altitude of the potentiometric surfaces in the aquifers in 1990 was determined on the assumption that the total rate of withdrawal would be $700 \mathrm{mgd}\left(2.65 \times 10^{6} \mathrm{~m}^{3} /\right.$ day $)$ in 1990 instead of 1980 . All other model conditions were the same as those in alternative $B$.

The decline in the altitude of the potentiometric surfaces in the lower unit of the Chicot aquifer and in the Chicot aquifer undifferentiated for 1890-1990 is shown on figure 37. The decline in the Evangeline aquifer are shown on figure 38. Both illustrations show that the declines did not increase appreciably more than the declines simulated in alternative B. 


\section{Alternative D}

This simulation was designed to show the declines in the altitudes of the poteniometric surfaces that would result from an increased withdrawal of $280 \mathrm{mgd}\left(1.06 \times 10^{6} \mathrm{~m}^{3} /\right.$ day $)$ more than the $1971-90$ pumping rate in alternative $C$.

The increase was modeled by the addition of a hypothetical well field located in northern Harris County. The problem is not designed to prove that a well field at this location could withdraw an additional $280 \mathrm{mgd}$, although this seems likely, but to show the declines that would result from the additional withdrawal of $280 \mathrm{mgd}$. This problem simulates an average total withdrawal rate of about $960 \mathrm{mgd}\left(3.63 \times 10^{6} \mathrm{~m}^{3} /\right.$ day $)$ for $1971-90$. Figure 39 shows the location of the hypothetical well field pumping from the Evangeline aquifer and the location of other new or expanded fields. 
The results of this simulation are shown on figures 39 and 40 . A comparison of figures 38 and 39 shows that the additional $280 \mathrm{mgd}$ ( 1.06 $\times 10^{6} \mathrm{~m}^{3} /$ day) of simulated pumping did not appreciably affect declines in the altitude of the potentiometric surface in the Evangeline aquifer south of Houston. A comparison of figures 37 and 40 shows that the additional $280 \mathrm{mgd}\left(1.06 \times 10^{6} \mathrm{~m}^{3} /\right.$ day $)$ of punping had very little effect on the altitude of the potentiometric surfaces in the lower unit of the Chicot aquifer and in the Chicot aquifer undifferentiated south of Houston.

The results indicate that total ground-water withdrawals of about $1,000 \mathrm{mgd}$ $\left(3.79 \times 10^{6} \mathrm{~m}^{3} /\right.$ day $)$ probably can be developed without greatly lowering the altitude of the potentiometric surface, in much of the district if the locations of the wells are carefully considered. The northern part of the district is especially suited for development because in this area, the Chicot aquifer undifferentiated has a water-table storage coefficient that results in minimal water-level declines as a result of pumping. The northern part of the district also has the highest vertical leakage, which allows water to move easily from the surface to the Chicot aquifer. 


\section{Limitations on Use of the Analog Model}

The values of the parameters modeled are rational values for the hydrologic system. Further investigation and new data will allow refinements to be made and will allow more accurate determination of the values for the parameters modeled.

The model was not designed to simulate the effects of one well over a short period of time. The model was designed to simulate the effects of withdrawal of water from a well field for periods of a year or longer.

The model was not designed to predict subsidence accurately; although, the simulation of clay compaction was included. Declines in the altitudes of the potentiometric surfaces are simulated, and these values can be used in calculations to predict subsidence.

Caution should be used in applying the modeled values in equations to predict short-term specific capacity of an individual well. The model simulates leaky-aquifer conditions with clay storage for time intervals greater than 1 year.

\section{Data Required for Improvement of the Model}

Observation wells that are screened in only one water-bearing unit are needed for better calibration of the model. The areas where measurements from such observation wells are needed are determined easily by noting the areas in which no potentiometric measurements are shown on figures 12 and 15. 
The accuracy of the model could be improved by better delineation of the water-bearing sands above the basal sand (Alta Loma Sand of Rose, 1943) of the lower unit of the Chicot in the Texas City area. To improve the correlation of observed and measured declines in the altitude of the potentiometric surface in the Texas City area, it was necessary to program extra pumpage.

More data are needed on the quantity of ground water pumped for irrigation in the vicinity of Dayton and Liberty and on the quantity of water discharged from flowing and pumped wells prior to 1930 in Galveston County.

The model could be modified to simulate clay compaction more accurately if the storage coefficient for clay compaction is determined accurately for each aquifer. In the present model, the storage coefficient for clay compaction is modeled as existing entirely between the land surface and the centerline of the lower unit of the Chicot aquifer and the Chicot aquifer undifferentiated. To distribute the storage coefficient accurately, more data concerning the characteristics of these clay layers are needed. These data can be obtained from consolidation tests on core samples, records of clay compaction from compaction recorders, and possibly from studies of various types of geophysical logs.

The present model could be modified to be one of the elements of a hybrid analog-digital model that could be used for detailed studies of such problems as salt-water encroachment and land-surface subsidence.

$$
\text { -49- }
$$


SURAARY

The Houston district has two major aquifers above the Burkeville confining layer. The uppermost aquifer is the Chicot aquifer, which consists of sand and clay layers that dip gently toward the Gulf of Mexico. In places in the Houston district, the Chicot aquifer can be separated into an upper and a lower unit.

The upper unit, which is not an important source of water for most of the district, can be defined where the altitude of the potentiometric surface differs from the altitude of the potentiometric surface in the lower unit. Where the upper unit cannot be defined, the aquifer is said to be undifferentiated.

The Evangeline aquifer, which is the major aquifer in the district, underlies the Chicot aquifer and consists of sand and clay layers that dip toward the Gulf of Mexico.

The Burkeville confining layer consists mostly of clay layers that form an effective barrier to ground-water flow at nearly all locations except at and near the outcrop of the Evangeline aquifer in Montgomery County. 
The large cones of depression in the potentiometric surfaces in the lower unit of the Chicot aquifer, the Chicot aquifer undifferentiated, and the Evangeline aquifer are caused by large withdrawals of water. Water now flows toward the center of these cones, creating a reversal of the original hydraulic gradient in most areas south of Houston. This reversal of the hydraulic gradient has resulted in salt-water encroachment toward the centers of the cones, but neither the location nor the rate of movement of the fresh-water salt-water interface is precisely known.

Land-surface subsidence in the Houston district is primarily caused by the compaction of clay layers within the aquifers. In most of the district, the most easily compressed clays are in the Chicot aquifer. Exclusive of water pumped from the upper unit of the Chicot aquifer, approximately 20 percent of the water pumped is derived from the compaction of sediments.

Statistical analysis of declines in the altitudes of the potentiometric surfaces and the time of the maximun rate of clay compaction of the Chicot aquifer in the NASA area indicates that the maximum rate of clay compaction occurs in less than 6 months after the decline in artesian pressure.

An electric analog model was constructed to study the hydrology of the area and to simulate the declines in the altitudes of the poteniometric surfaces for various alternatives of ground-water development. The modeled area was 9,100 square miles $(23,569$ square kilometers) with grid spacing of 1 square mile (2.590 square kilometers). 
The model was verified for declines in the altitudes of the potentiometric surfaces of both aquifers for 1890-1953, 1890-1960, and 1890-1970. In addition, the model was also verified for the volume of water derived from clay compaction. The hydrologic budget for model verification indicates that most of the water pumped results in depletion of storage in the water-table area of the lower unit of the Chicot aquifer and Chicot aquifer undifferentiated.

Movement of water vertically from the land surface to the centerline of the lower unit of the Chicot aquifer or Chicot aquifer undifferentiated, and water derived from clay compaction are also large sources of water. Water obtained from depletion of artesian storage and from inflow across the boundaries are minor sources.

Model verification indicated that: (1) The transmissivity of the aquifers is somewhat less than previously believed; (2) the exchange of water between aquifers through irrigation wells in the Katy area is an important element of the hydrologic budget; and (3) at Texas City, more detail is needed to model accurately the lower unit of the Chicot aquifer above the basal sand. 
Analysis of altemative plans for ground-water development emphasized the importance of defining the hydrologic budget. The results from alternative $A$ indicate that artificial recharge in the artesian area would significantly reduce subsidence and salt-water encroachment. Results from altemative $D$ indicate that ground-water pumping in the Houston district could be increased to about $1,000 \mathrm{mgd}\left(3.79 \times 10^{6} \mathrm{~m}^{3} /\right.$ day $)$ without serious $1 \mathrm{y}$ increasing subsidence or salt-water encroachment.

Withdrawals of ground-water in the water-table area of the Chicot aquifer undifferentiated would minimize declines in the altitudes of the potentiometric surfaces and, consequently, would minimize land-surface subsidence and salt-water encroachment.

The model could be modified to permit simulation of subsidence, or the model could be used in conjunction with other methods of problem solution to determine the extent and rate of salt-water encroachment. However, before the model can be modified to solve subsidence or saltwater encroachment problems, both problems need to be defined better. 


\section{REFERENCES CITED}

Anders, R. B., Mctdoo, G. D., and Alexander, W. H., Jr., 1968, Groundwater resources of Liberty County, Texas: Texas Water Devel. Board Rept. 72,154 p. 20 figs.

Gabrysch, R. K., 1969, Land-surface subsidence in the Houston-Galveston region, Texas: Internat. symposium on land subsidence, Tokyo, Japan, 1969, Proc., p. 43-54.

1972, Development of ground water in the Houston district, Texas, 1966-69: Texas Water Deve1. Board Rept. 152, 24 p., 18 figs.

Jacob, C. E., 1950, Flow of ground water in Rouse, H., ed., Engineering hydraulics: John Wiley \& Sons, New York, p. 321-386.

Jorgensen, D. G., and Ackroyd, E. A., 1973, Water resources of the Big Sioux River valley near Sioux Falls, South Dakata: U.S. Geol. Survey Water-Supply Paper 2024, 49 p.

Karplus, W. J., 1958, Analog simulation: McGraw-Hill Book Co., New York, $434 \mathrm{p}$.

Lang, J. W., Winslow, A. G., and White, W. N., 1950, Geology and groundwater resources of the Houston district, Texas: Texas Board Water Engin. Bull. 5001, 59 p.

Lohman, S. W., 1972, Ground-water hydraulics: U.S. Geol. Survey Professional Paper 708, $69 \mathrm{p}$.

Patten, E. P., Jr., 1965, Design, construction, and use of electric analog models in Wood, L. A., and Gabrysch, R. K., Analog model study of ground water in the Houston district, Texas: Texas Water Comm. Bull. 6508, p. $41-103$ 


\section{REFERENCES CITED--Continued}

Pettit, B. M., Jr., and Winslow, A. G., 1957, Geology and ground-water resources of Galveston County, Texas: U.S. Geol. Survey Water-Supply Paper 1416, $157 \mathrm{p}$.

Popkin, B. P., 1971, Ground-water resources of Montgomery County, Texas: Texas Water Devel. Board Rept. 136, 149 p., 29 figs.

Rose, N. A., 1943, Progress report on the ground-water resources in the Texas City area, Texas: U.S. Geol. Survey open-file rept., 45 p., 4 figs. Sandeen, W. M., and Wesselman, J. B., 1973, Ground-water resources of Brazoria County, Texas: Texas Water Devel. Board Rept. 163, 199 p., 29 figs.

Sternberg, Y. M., 1973, Efficiency of partially penetrating wells: -Ground Water, v. 11, no.3, p. 5-8.

Turner, Collie and Braden, Inc., Consulting Engineers, 1966, Comprehensive study of Houston's municipal water system, phase 1 - basic studies, section 1 - municipal water demands, ground-water potential: Turner, Collie and Braden, Inc., Consulting Engin., 50 p., 30 figs., 3 pls. 1972, Comprehensive study of Houston's municipal water system, phase 3 - distribution system and overall cost scheduling, section 5 - distribution system - analysis and design, section 6 - cost estimates and scheduling of recommended improvements: Turner, Collie and Braden, Inc., Consulting Engin., 65 p.

Walton, W. C., and Prickett, T. A., 1963, Hydrogeologic electric analog computers: Am. Soc. Civil Engineers Proc., Jour. Hydraulics Div., p. $67-89$. 


\section{REFERENCES CITED--Continued}

Wesselman, J. B., 1971, Ground-nater resources of Chambers and Jefferson

Counties, Texas: Texas Water Devel. Board Rept. 133, 183 p., 28 figs. 1972, Ground-water resources of Fort Bend County, Texas: Texas

Water Deve1. Board Rept. 155, 185 p., 33 figs.

Wilson, C. A., 1967, Ground-water resources of Austin and Waller Counties,

Texas: Texas Water Deve1. Board Rept. 68,79 p., 12 figs.

Winslow, A. G., and Doyel, W. W., 1954, Land-surface subsidence and its

relation to the withdrawal of ground water in the Houston-Galveston region, Texas: Econ. Geology, v. 49, no. 4, p. 413-422.

Winslow, A. G., Doyel, W. W., and Hood, L. A., 1957, Salt water and its relation to fresh ground water in Harris County, Texas: U.S. Geol. Survey Water-Supply Paper 1360-F, p. 375-407, .11 figs.

Winslow, A. G., and Wood, L. A., 1959, Relation of land subsidence to ground-water withdrawals in the upper Gulf Coast region, Texas: Mining Engin., v. 11, no. 10, p. 1030-1034. Wolfskil1, L. A., 1960, The consolidation characteristics of undisturbed soil samples of deep formations and thier application to problems of regional subsidence: Texas AEM Univ., unpubl. masters thesis, $70 \mathrm{p}$. Wood, L. A., and Gabrysch, R. K., 1965, Analog model study of ground water in the Houston district, Texas: Texas Water Comm. Bull. 7508, 103 p., 43 figs. 


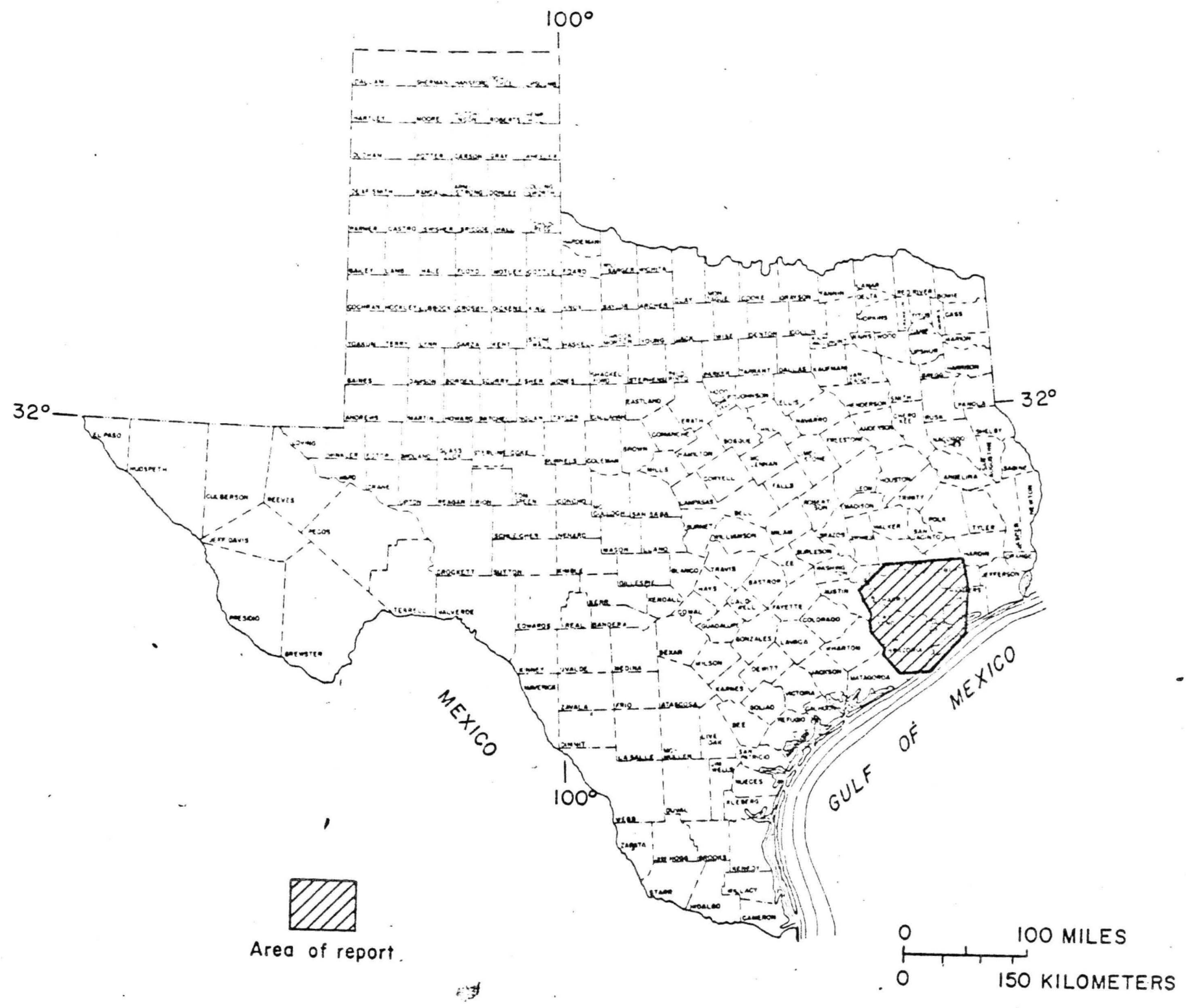

FIGURE 1.- Location and extent of the Houston district page 72 follow: 


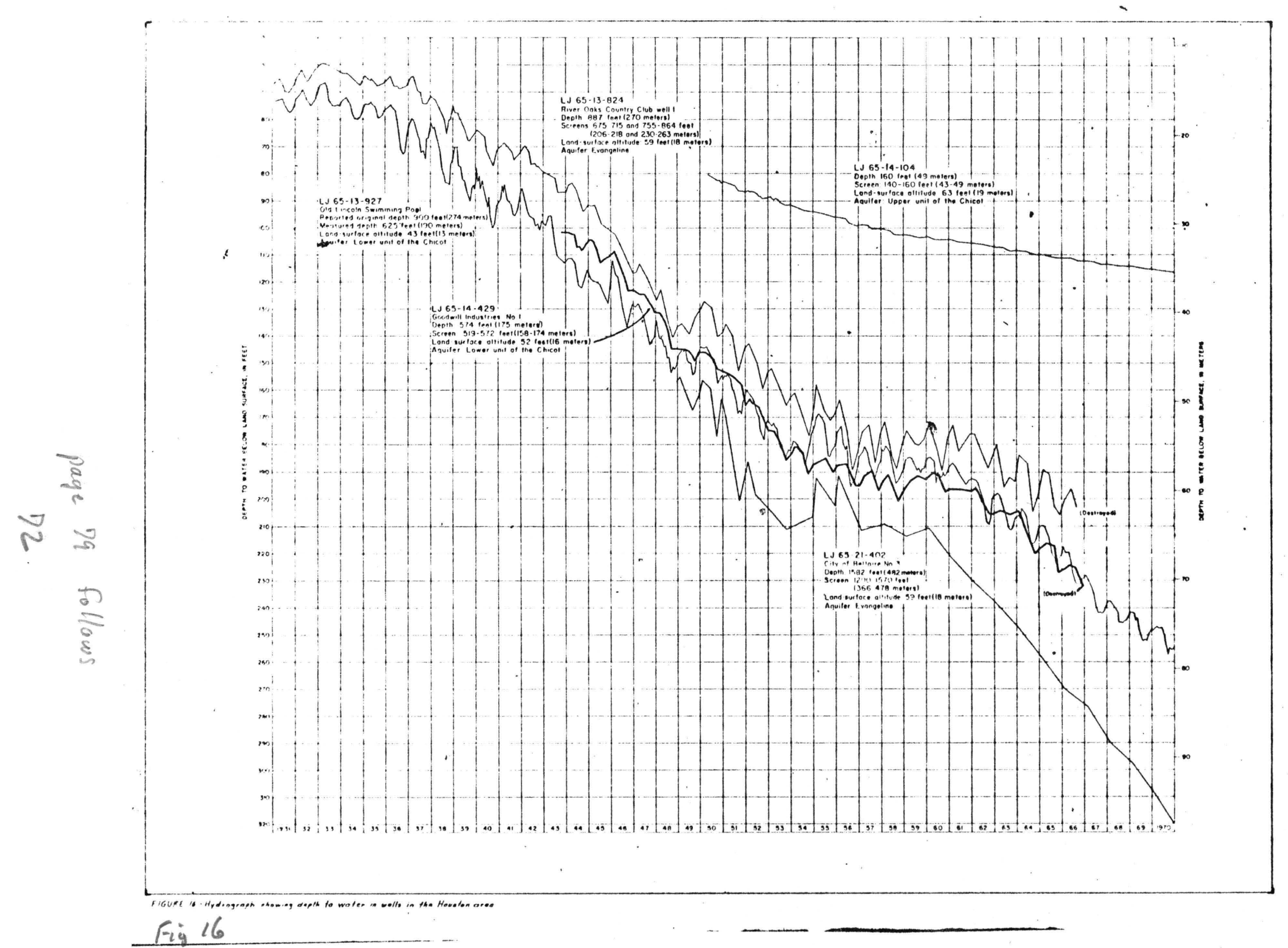




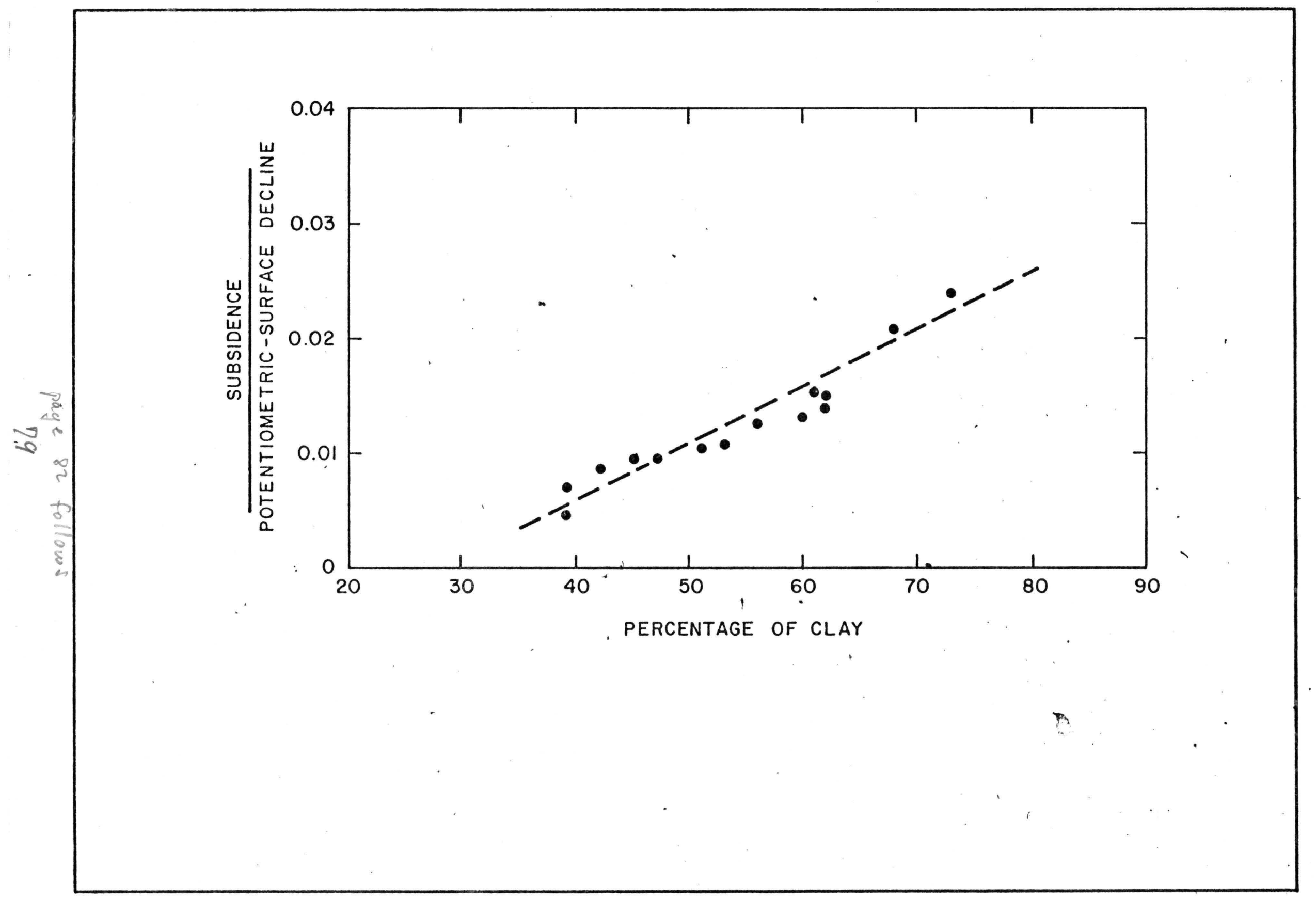

FIGURE 23.- Relation of land-surface subsidence to the decline in the altitude of the potentiometric surface and the percentage of clay in an aquifer 


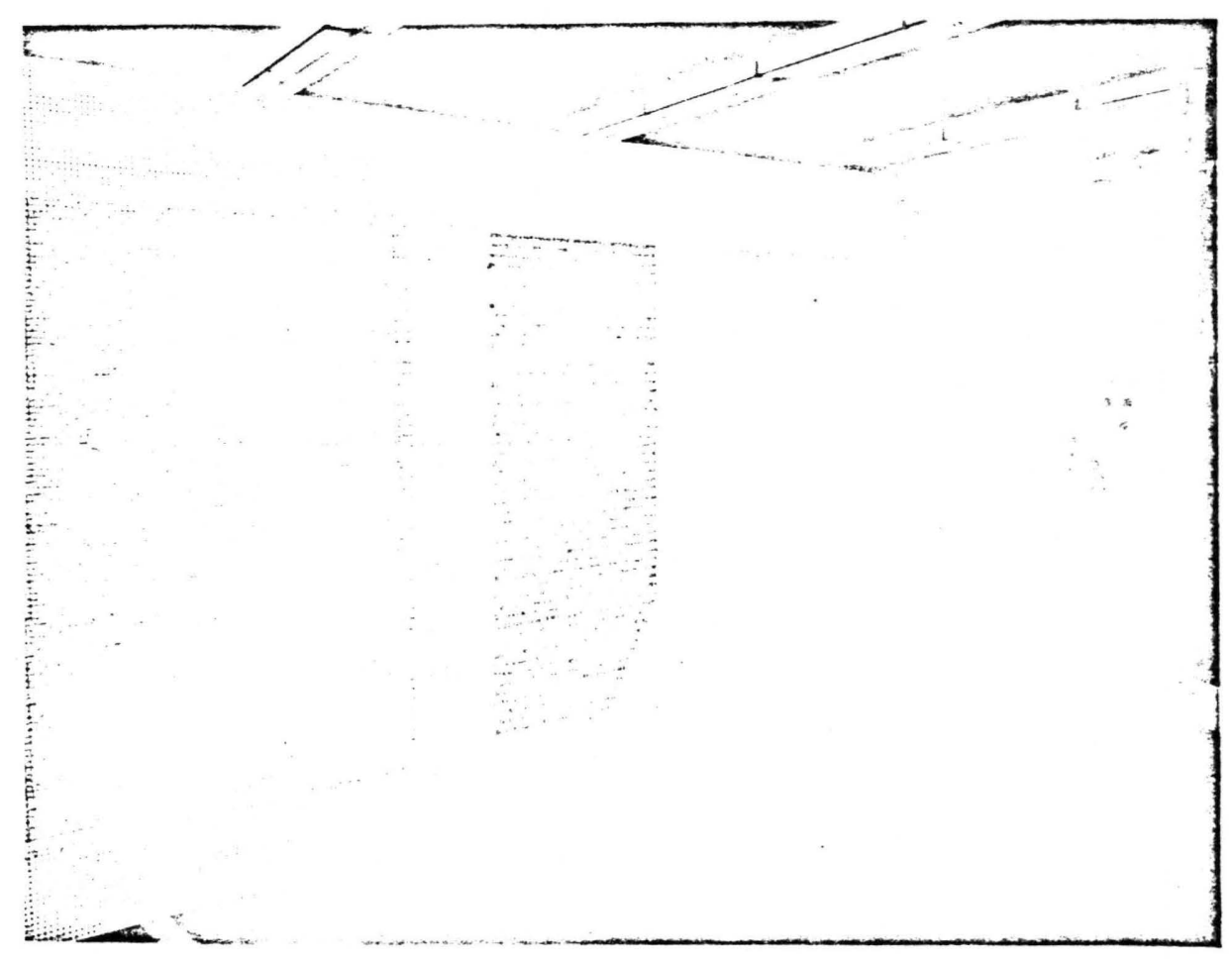

(a) Front view of model and oscilloscope

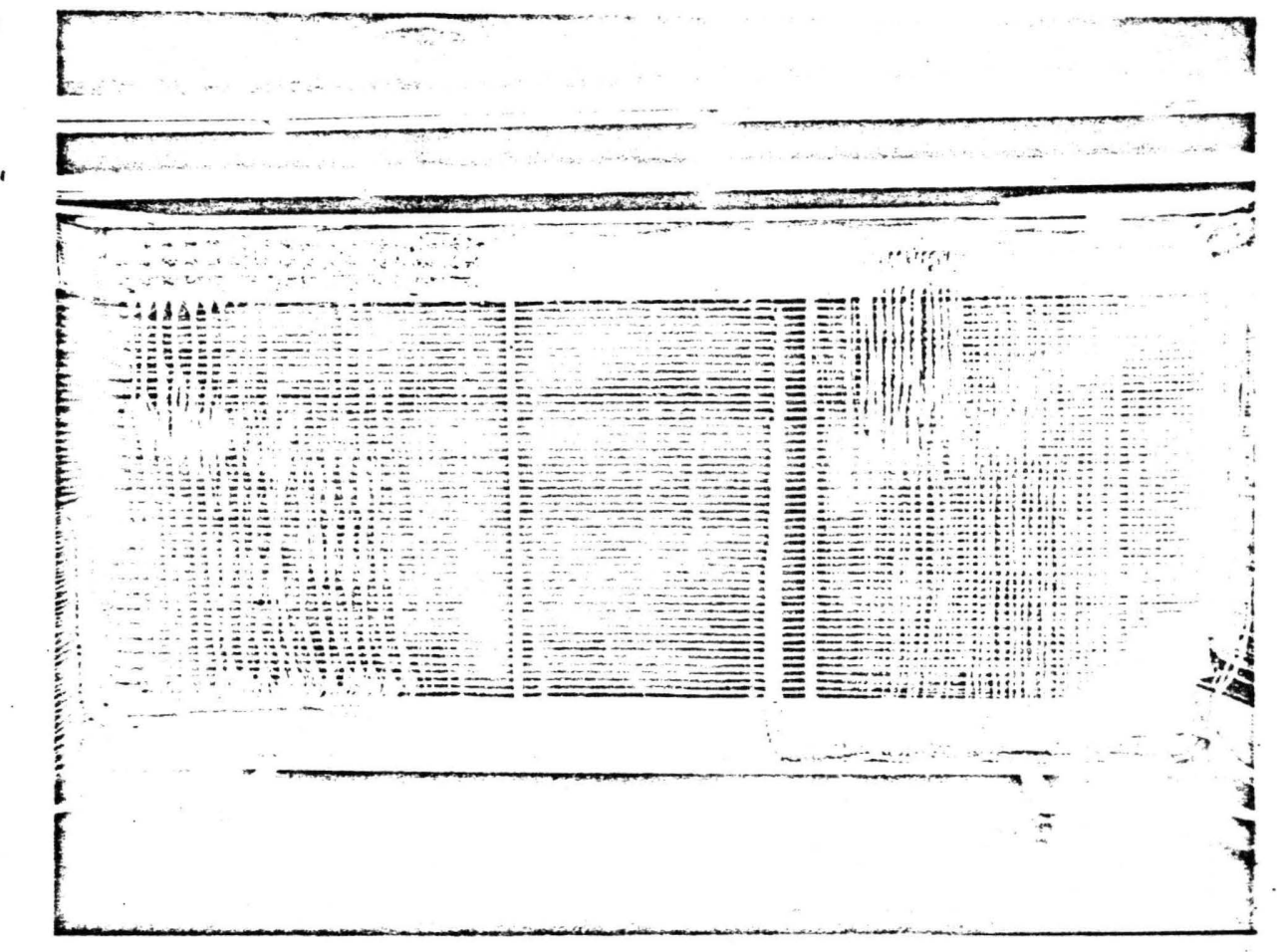

(b) Back view of model

Figure 26.--Electric analog model of the Houston district 


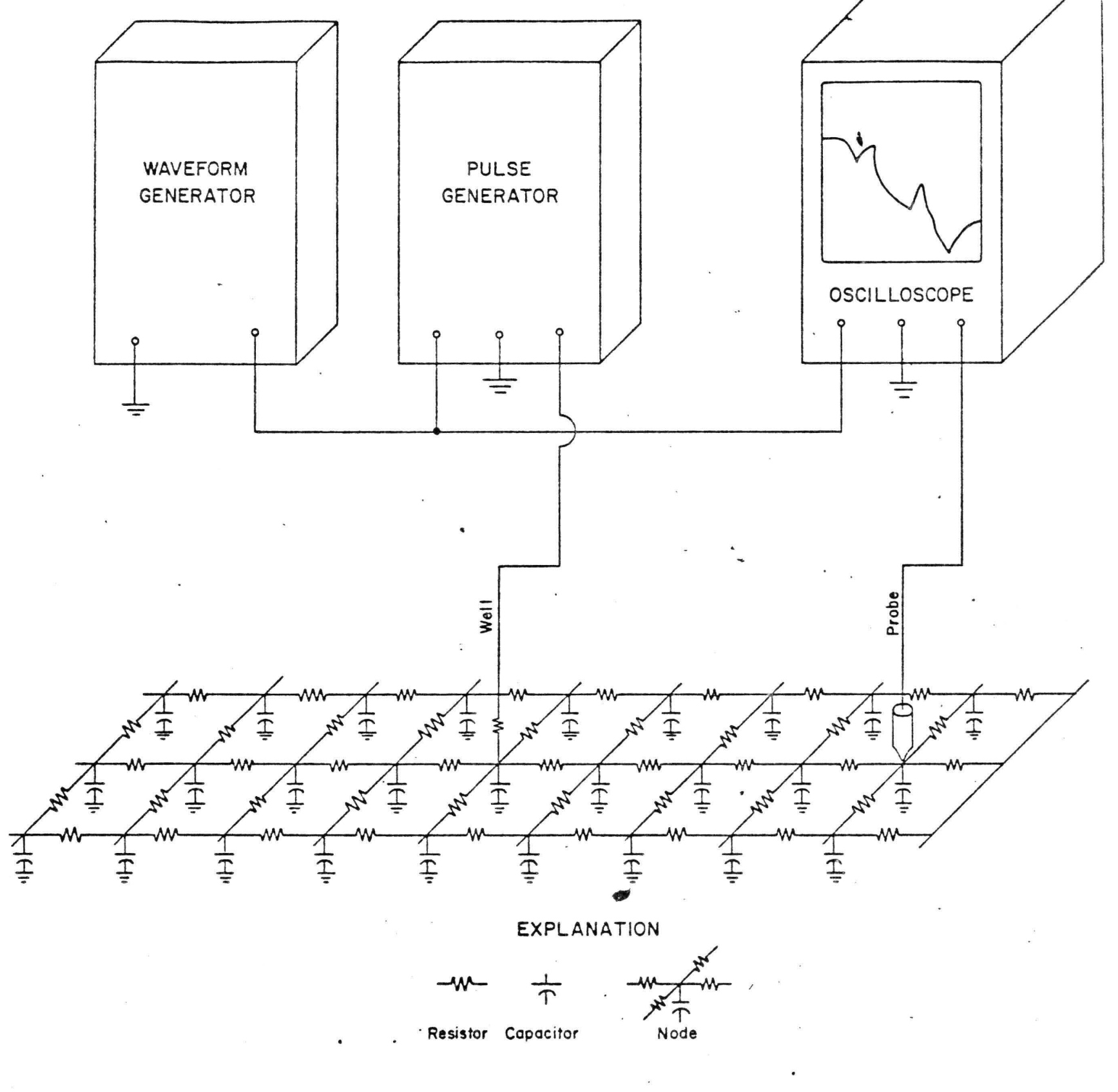

FIGURE 27. - Simple electric onolog model 


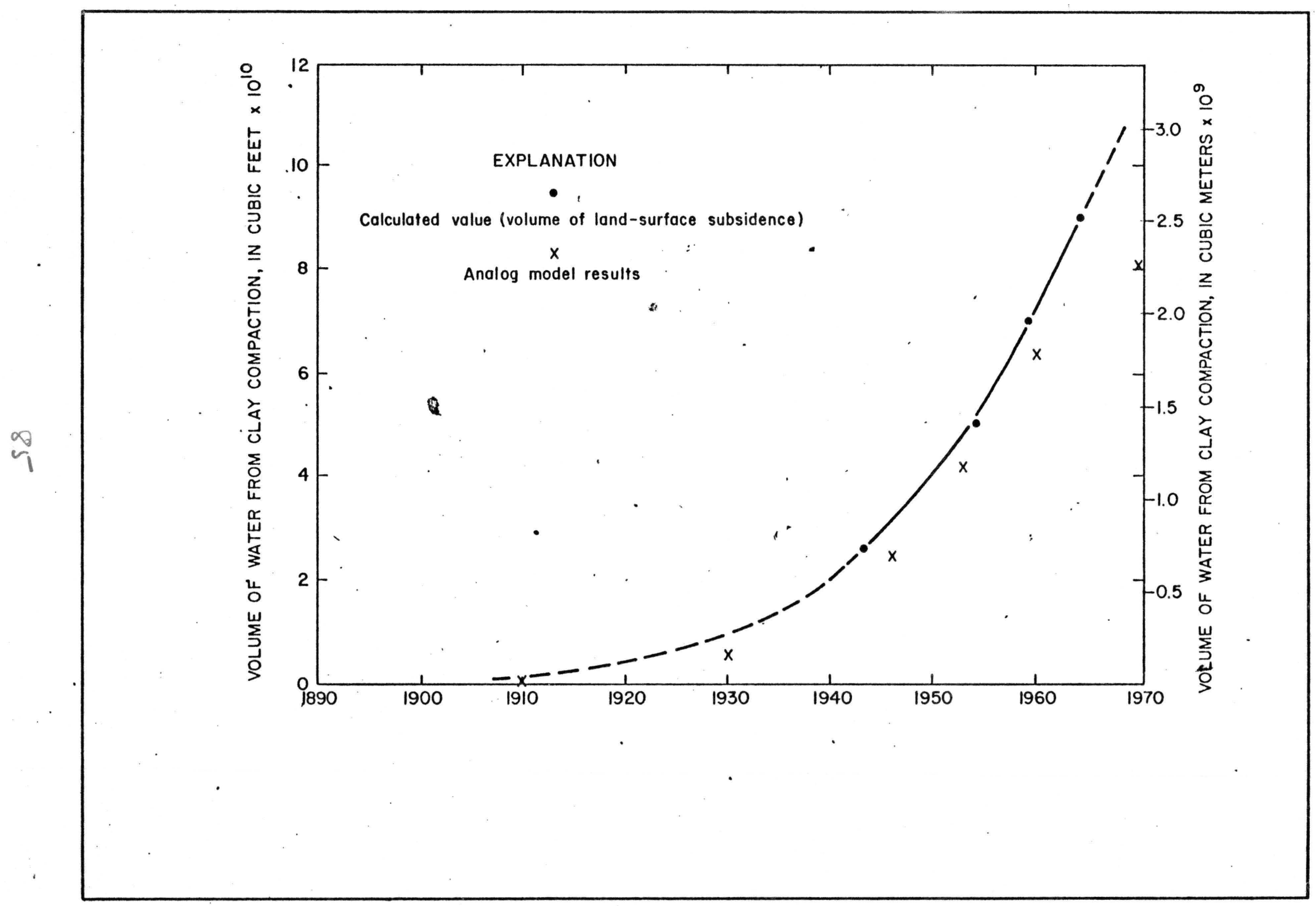

FIGURE 29. - Volume of water derived from clay compaction 


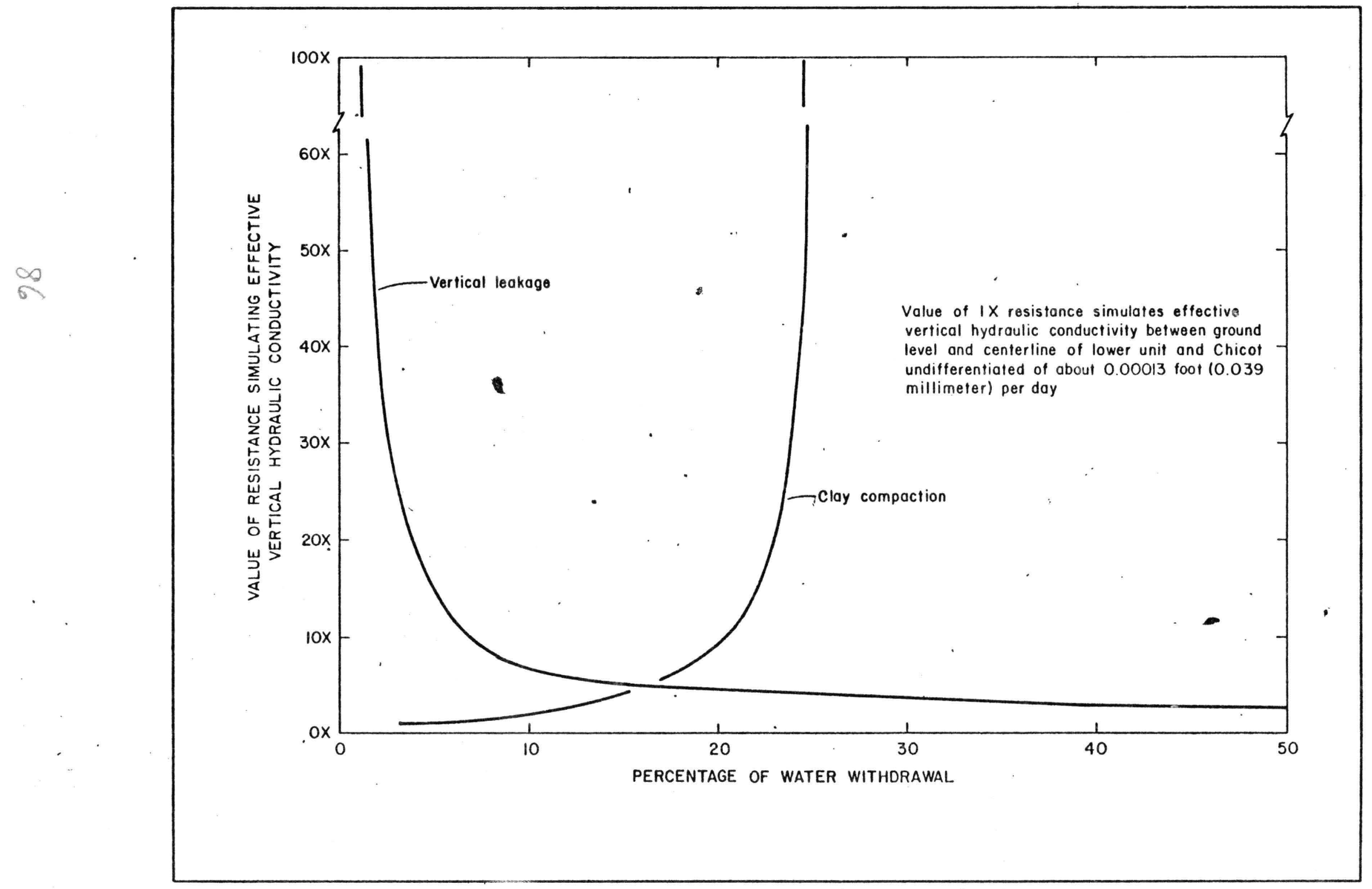

FIGURE 30--Sensitivity of the model to vertical hydraulic conductivity 